Effects of Glen Canyon Dam Discharges on Water Velocity and Temperatures at the Confluence of the Colorado and Little Colorado Rivers and Implications for Habitat for Young-of-Year Humpback Chub (Gila cypha)

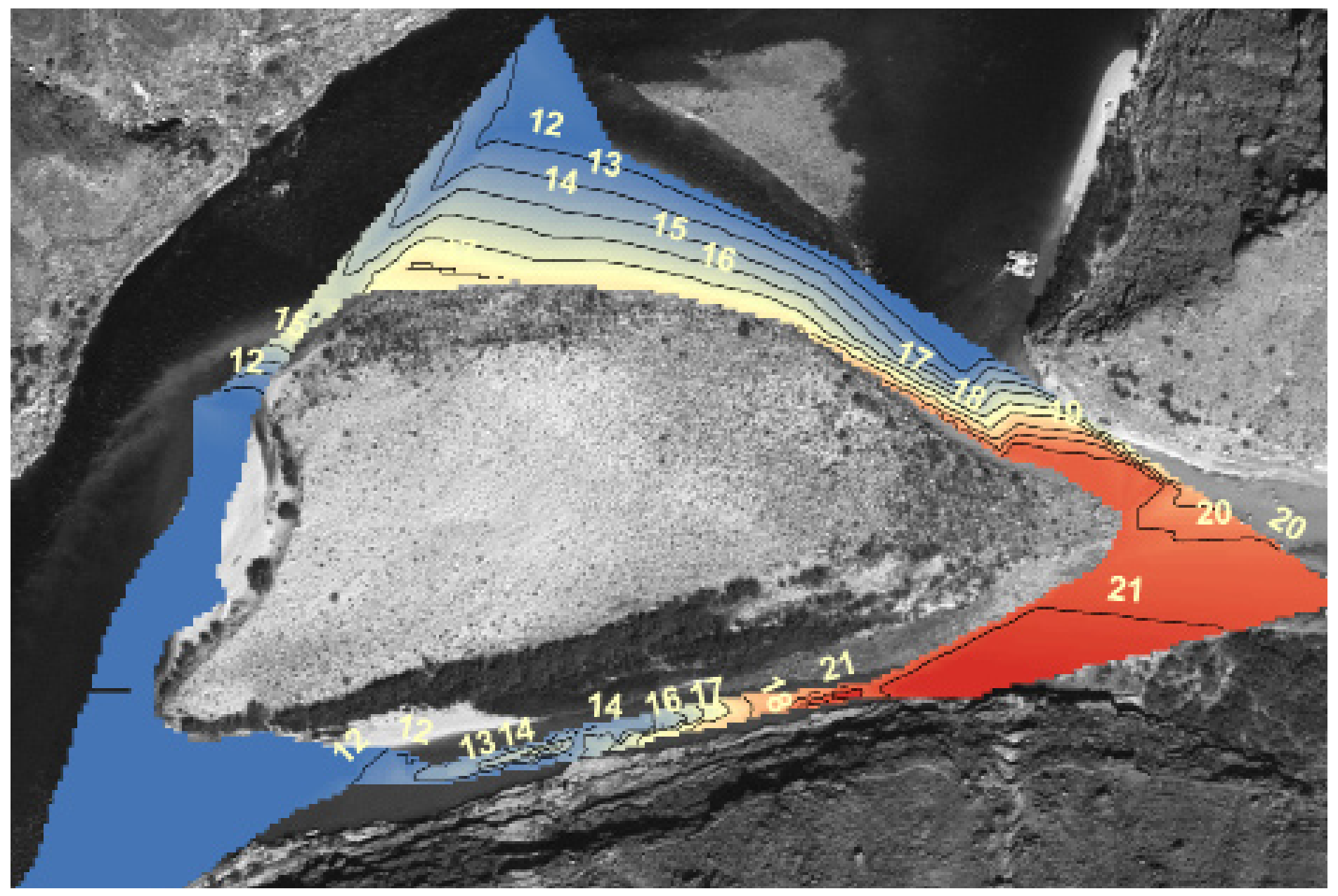

Open-File Report 2010-1137 
Cover: $1^{\circ} \mathrm{C}$ temperature contours overlaid on an aerial digital photograph of the confluence of the Colorado and Little Colorado Rivers (USGS photo). Temperature values are for mainstem discharge at $227 \mathrm{~m}^{3} / \mathrm{s}$ and Little Colorado River base flow of $6.3 \mathrm{~m}^{3} / \mathrm{s}$. 
Prepared in cooperation with Shephard-Wesnitzer, Inc.

Effects of Glen Canyon Dam Discharges on Water Velocity and Temperatures at the Confluence of the Colorado and Little Colorado Rivers and Implications for Habitat for Young-of-Year Humpback Chub (Gila cypha)

By Frank R. Protiva, Barbara E. Ralston, Dennis M. Stone, Keith A. Kohl, Michael D. Yard, and G. Allen Haden

Open-File Report 2010-1137

U.S. Department of the Interior U.S. Geological Survey 


\section{U.S. Department of the Interior \\ KEN SALAZAR, Secretary}

\section{U.S. Geological Survey \\ Marcia K. McNutt, Director}

U.S. Geological Survey, Reston, Virginia 2010

For product and ordering information:

World Wide Web: http://www.usgs.gov/pubprod

Telephone: 1-888-ASK-USGS

For more information on the USGS—-the Federal source for science about the Earth, its natural and living resources, natural hazards, and the environment:

World Wide Web: http://www.usgs.gov

Telephone: 1-888-ASK-USGS

Suggested citation:

Protiva, F.R., Ralston, B.E., Stone, D.M., Kohl, K.A., Yard, M.D., and Haden, G.A., 2010, Effects of Glen Canyon Dam discharges on water velocity and temperatures at the confluence of the Colorado and Little Colorado Rivers and implications for habitat for young-of-year humpback chub (Gila cypha): U.S. Geological Survey Open-File Report 2010-1137, 24 p. [http://pubs.usgs.gov/of/2010/1137/].

Any use of trade, product, or firm names is for descriptive purposes only and does not imply endorsement by the U.S. Government.

Although this report is in the public domain, permission must be secured from the individual copyright owners to reproduce any copyrighted material contained within this report. 


\section{Contents}

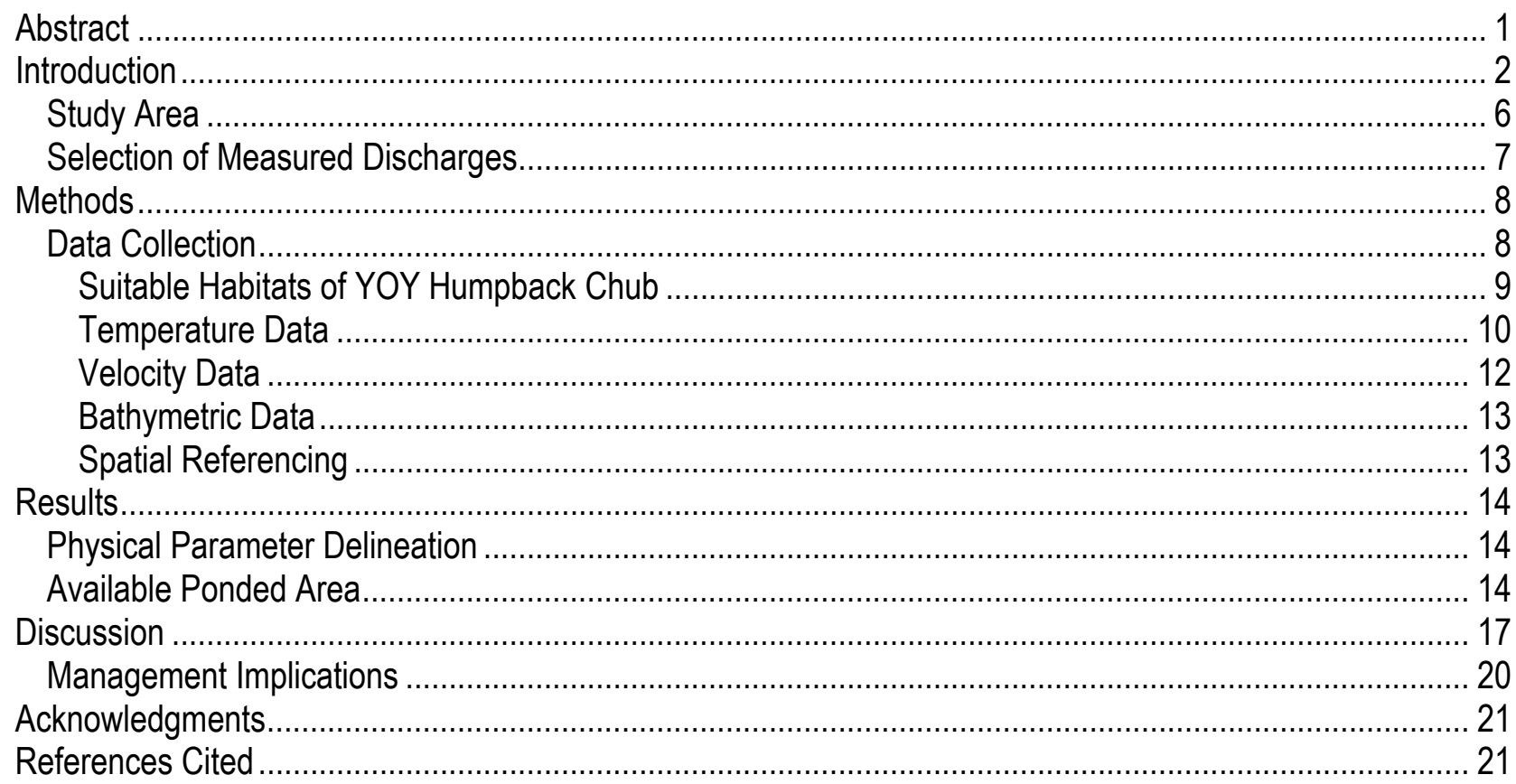

\section{Figures}

1. Map showing segments of the Colorado River and the Little Colorado River near their confluence $\ldots . .2$

2. Aerial black and white digital imagery from September 2000 of the confluence area of the Colorado River and the Little Colorado River taken when mainstem discharge was $226 \mathrm{~m}^{3} / \mathrm{s}$.

3. Line graph contrasting the predam and postdam mean daily discharge of the Colorado River, compared with the discharge pattern of the Little Colorado River.

4. Illustration showing where water temperature data were collected in the study area

5. Side-by-side figures of the confluence study area when mainstem discharge is $227 \mathrm{~m}^{3} / \mathrm{s}$ and LCR discharge is at base flow $\left(6.3 \mathrm{~m}^{3} / \mathrm{s}\right)$

6. Side-by-side figures of the confluence study area when mainstem discharge is $368 \mathrm{~m}^{3} / \mathrm{s}$ and LCR discharge is at base flow $\left(6.3 \mathrm{~m}^{3} / \mathrm{s}\right)$ 
7. Side-by-side figures of the confluence study area when mainstem discharge is $538 \mathrm{~m}^{3} / \mathrm{s}$ and LCR

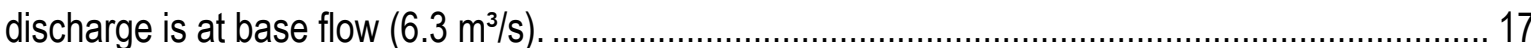

\section{Tables}

1. Dates associated with temperature, velocity, and bathymetric data capture at the confluence of the Colorado and Little Colorado Rivers. 9

2. Available low-velocity $(0.2 \mathrm{~m} / \mathrm{s})$ area and low-velocity, warmwater area $\left(0.2 \mathrm{~m} / \mathrm{s}, \geq 16^{\circ} \mathrm{C}\right)$ associated with four mainstem discharges at the Little Colorado River confluence. 15 


\section{Conversion Factors}

Inch/Pound to SI

\begin{tabular}{|c|c|c|}
\hline Multiply & By & To obtain \\
\hline \multicolumn{3}{|c|}{ Length } \\
\hline inch (in.) & 2.54 & centimeter $(\mathrm{cm})$ \\
\hline inch (in.) & 25.4 & millimeter $(\mathrm{mm})$ \\
\hline foot (ft) & 0.3048 & meter $(\mathrm{m})$ \\
\hline mile (mi) & 1.609 & kilometer $(\mathrm{km})$ \\
\hline \multicolumn{3}{|c|}{ Area } \\
\hline acre & 4,047 & square meter $\left(\mathrm{m}^{2}\right)$ \\
\hline acre & 0.4047 & hectare (ha) \\
\hline square foot $\left(\mathrm{ft}^{2}\right)$ & 929.0 & square centimeter $\left(\mathrm{cm}^{2}\right)$ \\
\hline square foot $\left(\mathrm{ft}^{2}\right)$ & 0.09290 & square meter $\left(\mathrm{m}^{2}\right)$ \\
\hline square inch $\left(\mathrm{in}^{2}\right)$ & 6.452 & square centimeter $\left(\mathrm{cm}^{2}\right)$ \\
\hline \multicolumn{3}{|c|}{ Volume } \\
\hline cubic foot $\left(\mathrm{ft}^{3}\right)$ & 0.02832 & cubic meter $\left(\mathrm{m}^{3}\right)$ \\
\hline \multicolumn{3}{|c|}{ Flow rate } \\
\hline acre-foot per day (acre-ft/d) & 0.01427 & cubic meter per second $\left(\mathrm{m}^{3} / \mathrm{s}\right)$ \\
\hline acre-foot per year (acre-ft/yr) & 1,233 & cubic meter per year $\left(\mathrm{m}^{3} / \mathrm{yr}\right)$ \\
\hline acre-foot per year (acre-ft/yr) & 0.001233 & $\begin{array}{l}\text { cubic hectometer per year } \\
\left(\mathrm{hm}^{3} / \mathrm{yr}\right)\end{array}$ \\
\hline foot per second (ft/s) & 0.3048 & meter per second $(\mathrm{m} / \mathrm{s})$ \\
\hline cubic foot per second $\left(\mathrm{ft}^{3} / \mathrm{s}\right)$ & 0.02832 & cubic meter per second $\left(\mathrm{m}^{3} / \mathrm{s}\right)$ \\
\hline
\end{tabular}

Temperature in degrees Celsius $\left({ }^{\circ} \mathrm{C}\right)$ may be converted to degrees Fahrenheit $\left({ }^{\circ} \mathrm{F}\right)$ as follows:

${ }^{\circ} \mathrm{F}=\left(1.8 x^{\circ} \mathrm{C}\right)+32$

Temperature in degrees Fahrenheit $\left({ }^{\circ} \mathrm{F}\right)$ may be converted to degrees Celsius $\left({ }^{\circ} \mathrm{C}\right)$ as follows:

${ }^{\circ} \mathrm{C}=\left({ }^{\circ} \mathrm{F}-32\right) / 1.8$

Vertical coordinate information is referenced to the insert datum name (and abbreviation) here for instance, "North American Vertical Datum of 1988 (NAVD 88)."

Horizontal coordinate information is referenced to the insert datum name (and abbreviation) here for instance, "North American Datum of 1983 (NAD 83)." 


\title{
Effects of Glen Canyon Dam Discharges on Water Velocity and Temperatures at the Confluence of the Colorado and Little Colorado Rivers and Implications for Habitat for Young-of-Year Humpback Chub (Gila cypha)
}

By Frank R. Protiva, ${ }^{1}$ Barbara E. Ralston, ${ }^{2}$ Dennis M. Stone, ${ }^{3}$ Keith A. Kohl, ${ }^{2}$ Michael D. Yard, ${ }^{2}$ and G. Allen Haden 4

\begin{abstract}
Water velocity and temperature are physical variables that affect the growth and survivorship of young-of-year (YOY) fishes. The Little Colorado River, a tributary to the Colorado River in Grand Canyon, is an important spawning ground and warmwater refuge for the endangered humpback chub (Gila cypha) from the colder mainstem Colorado River that is regulated by Glen Canyon Dam. The confluence area of the Little Colorado River and the Colorado River is a site where YOY humpback chub (size 30-90 mm) emerging from the Little Colorado River experience both colder temperatures and higher velocities associated with higher mainstem discharge. We used detailed surveying and mapping techniques in combination with YOY velocity and temperature preferenda (determined from field and lab studies) to compare the areal extent of available habitat for young fishes at the confluence area under four mainstem discharges $(227,368$, 504 , and $878 \mathrm{~m}^{3} / \mathrm{s}$ ). Comparisons revealed that the areal extent of low-velocity, warm water at the confluence decreased when discharges exceeded $368 \mathrm{~m}^{3} / \mathrm{s}$. Furthermore, mainstem fluctuations, depending on the rate of upramp, can affect velocity and temperature dynamics in the confluence area within several hours. The amount of daily fluctuations in discharge can result in the loss of approximately 1.8 hectares of habitat favorable to YOY humpback chub. Consequently, flow fluctuations and the accompanying changes in velocity and temperature at the confluence may diminish the recruitment potential of humpback chub that spawn in the tributary stream. This study illustrates the utility of multiple georeferenced data sources to provide critical information related to the influence of the timing and magnitude of discharge from Glen Canyon Dam on potential rearing environment at the confluence area of the Little Colorado River.
\end{abstract}

\footnotetext{
${ }^{1}$ Shepard-Wesnitzer, Inc., 110 West Dale Ave., Flagstaff, AZ 86001; deceased.

${ }^{2}$ U.S. Geological Survey, Southwest Biological Science Center, Grand Canyon Monitoring and Research Center, 2255 N. Gemini Drive, Flagstaff, AZ 86001

${ }^{3}$ U.S. Fish and Wildlife Service, Arizona Fishery Resources Office, P.O. Box 338, Flagstaff, AZ 86002-0338

${ }^{4}$ Natural Channel Design, Inc., 206 S. Eldon St., Flagstaff, AZ 86001
} 


\section{Introduction}

Glen Canyon Dam and its operations reduce Colorado River temperatures and destabilize shoreline environments for fish (Minckley, 1991; Converse and others, 1998; Vernieu and others, 2005). Recruitment failure by native fish in the Colorado River in Grand Canyon is attributed to these and other factors (Kaeding and Zimmerman, 1983; Minckley, 1991; Converse and others, 1998; Gorman and Stone, 1999; Korman and others, 2004). Humpback chub (Gila cypha), one of four native fish still found in Grand Canyon, was federally listed as an endangered species on March 11, 1967 (U.S. Federal Register 32:48:4001), just 21 years after Miller (1946) described it as a new species. Currently, the largest of six remnant populations resides in the Colorado River below Glen Canyon Dam within Grand Canyon National Park (fig. 1) and the lower $14 \mathrm{~km}$ of the Little Colorado River (LCR) on Navajo tribal lands, Arizona (U.S. Fish and Wildlife Service, 1990; Douglas and Marsh, 1996; Coggins and Walters, 2009).

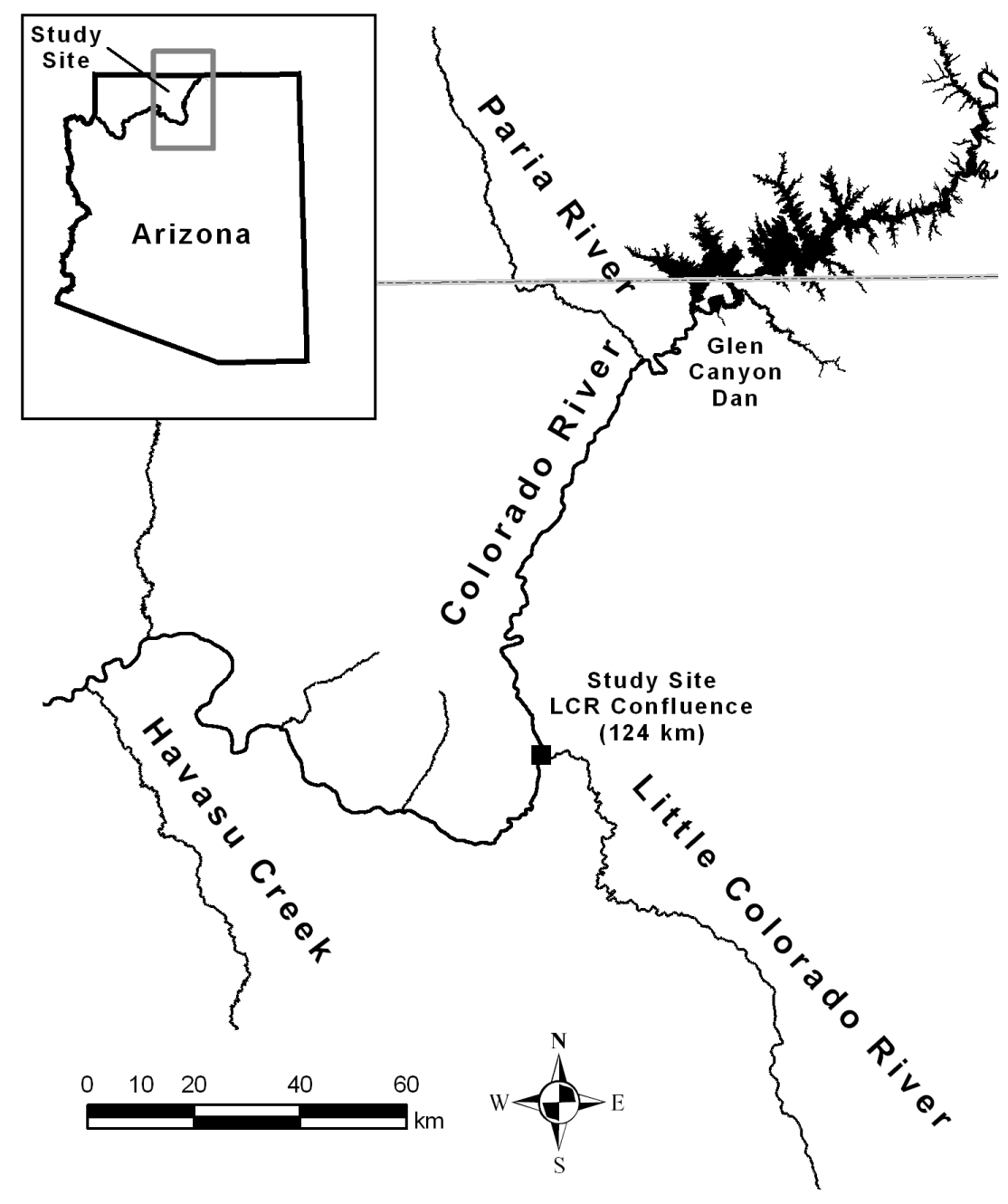

Figure 1. Map showing segments of the Colorado River and the Little Colorado River near their confluence. The confluence of these rivers is located $124 \mathrm{~km}$ (76 river miles) below Glen Canyon Dam. 
Historically, humpback chub spawned, matured, and recruited throughout both rivers in Grand Canyon (Minckley, 1991), but these activities have been largely curtailed in the Colorado River since its transformation into a regulated tailwater in 1963 (Minkley, 1991; Valdez and Ryel, 1995). Whereas annual water temperatures ranged from 2 to $26^{\circ} \mathrm{C}$ at Lees Ferry before Glen Canyon Dam (Stanford and Ward, 1991), the subsequent hypolimnetic withdrawal from Lake Powell has stabilized the water-temperature fluctuations to a consistently cold $8-12^{\circ} \mathrm{C}$ at Lees Ferry in most years (Vernieu and others, 2005; Voichick and Wright, 2007). Water released from Glen Canyon Dam warms as it travels toward Lake Mead, but initial release temperatures and volumes, time of year, and local ambient conditions affect rates of downstream warming (Anderson and Wright, 2007; Wright and others, 2008). Initial release temperature from Glen Canyon Dam affects water temperatures in the first $150 \mathrm{~km}$ of the river more than release volume. The mainstem temperatures are generally $2^{\circ} \mathrm{C}$ warmer than the initial release temperatures by the time water reaches the LCR confluence area. In most years, Colorado River temperatures do not exceed $14^{\circ} \mathrm{C}$ near the confluence area of the LCR (Voichick and Wright, 2007).

Water temperatures below $12^{\circ} \mathrm{C}$ inhibit spawning, embryonic development, and juvenile growth of humpback chub (Hamman, 1982; Marsh, 1985; Clarkson and Childs, 2000; Robinson and Childs, 2001). Reduced temperatures and other factors have also been implicated in the decline or extirpation of other endemic, warmwater fish species in the Grand Canyon portion of the Colorado River, such as the Colorado pikeminnow (Ptychocheilus lucius), bonytail chub (Gila elegans), and razorback sucker (Xyrauchen texanus). Furthermore, the ichthyofauna of this reach, near the LCR, is now dominated by nonnative rainbow trout (Oncorhynchus mykiss) and brown trout (Salmo trutta), which thrive under these colder water temperatures and have become substantial competitors and predators of humpback chub, especially the younger life stages of humpback chub (Minckley, 1991; Gloss and Coggins, 2005; Gorman and others, 2005). Thus, the perpetuation of the Grand Canyon population of humpback chub has become dependent on the lower LCR, where existing river conditions are still thermally conducive for their successful reproduction and ontogenetic development to adulthood (Gorman and Stone, 1999; Stone and Gorman, 2006).

Resource managers cannot solely rely on the LCR to safeguard the Grand Canyon humpback chub population from extinction. For example, the adult population experienced an estimated 40-50 percent decline between 1990 and 2000, despite continued reproduction in the LCR (Coggins and others, 2006a; Coggins, 2008; Coggins and Walters, 2009). Many adult humpback chub are characterized as potamodromous, undergoing migrations between rivers for spawning purposes (Gorman and Stone, 1999). Each spring adult humpback chub from the Colorado River migrate up the LCR and merge with resident adults to spawn (Gorman and Stone, 1999). The offspring that recruit to adulthood are primarily those that remain in the LCR to rear and complete the bulk of their ontogenesis (Kaeding and Zimmerman, 1983; Robinson and others, 1998; Gorman and Stone, 1999). Many larval humpback chub ( $\leq 29 \mathrm{~mm}$ total length (TL)) passively drift or are involuntarily flushed downriver during tributary spates and into the Colorado River, where they are immediately exposed to cold water temperatures. Cold water temperatures (less than $12^{\circ} \mathrm{C}$ ) can induce thermal shock, stifle growth, and make them vulnerable to piscivory (Robinson and others, 1998; Clarkson and Childs, 2000; Gorman and others, 2005). Although older, post larval young-of-year (YOY) humpback chub (30-90 mm TL) are better developed morphologically and less prone to drift than smaller larval life stages, many individuals still become displaced into the Colorado River during tributary spates, associated with heavy rains, where they are subject to similar deleterious outcomes. Movement out of the LCR by young fish 
may also be associated with carrying capacity of the LCR (Minkley, 1991; Oberlin and others, 1999; Stone and Gorman, 2006). In the absence of alternative sources for humpback chub recruitment and because the likelihood of humpback chub surviving in the Colorado River increases for larger sized fish, maximizing the time that YOY remain and grow in the LCR and its confluence area before entering the Colorado River could contribute to increased recruitment for this species.

The LCR confluence area is hydrologically complex because of a large cobble bar island (ca. 6 hectares (ha)) that is situated near the LCR mouth and influences mainstem water circulation and interactions with LCR discharges (fig. 2). The confluence area is also the last chance for passively drifting YOY humpback chub, or fish being flushed downriver, to find refuge within warmwater, low velocity (less than $0.2 \mathrm{~m} / \mathrm{s}$ ) environments before entering the Colorado River. During periods of time when the LCR discharge is at base flow $\left(6.3 \mathrm{~m}^{3} / \mathrm{s}\right.$ approximately 7 months/year, Johnson and Sanderson, 1968; U.S. Geological Survey, 2010; fig. 3), the velocity, depth, and total ponded area of the LCR confluence depend directly on the Colorado River's discharge and its interaction with the island (fig. 2). The diel discharge fluctuations from Glen Canyon Dam, the mainstem river temperatures, and the temperatures of the LCR can alter the extent of water velocities and temperatures amenable to YOY humpback chub growth and movement at the LCR-island confluence area (Robinson and others, 1998). 

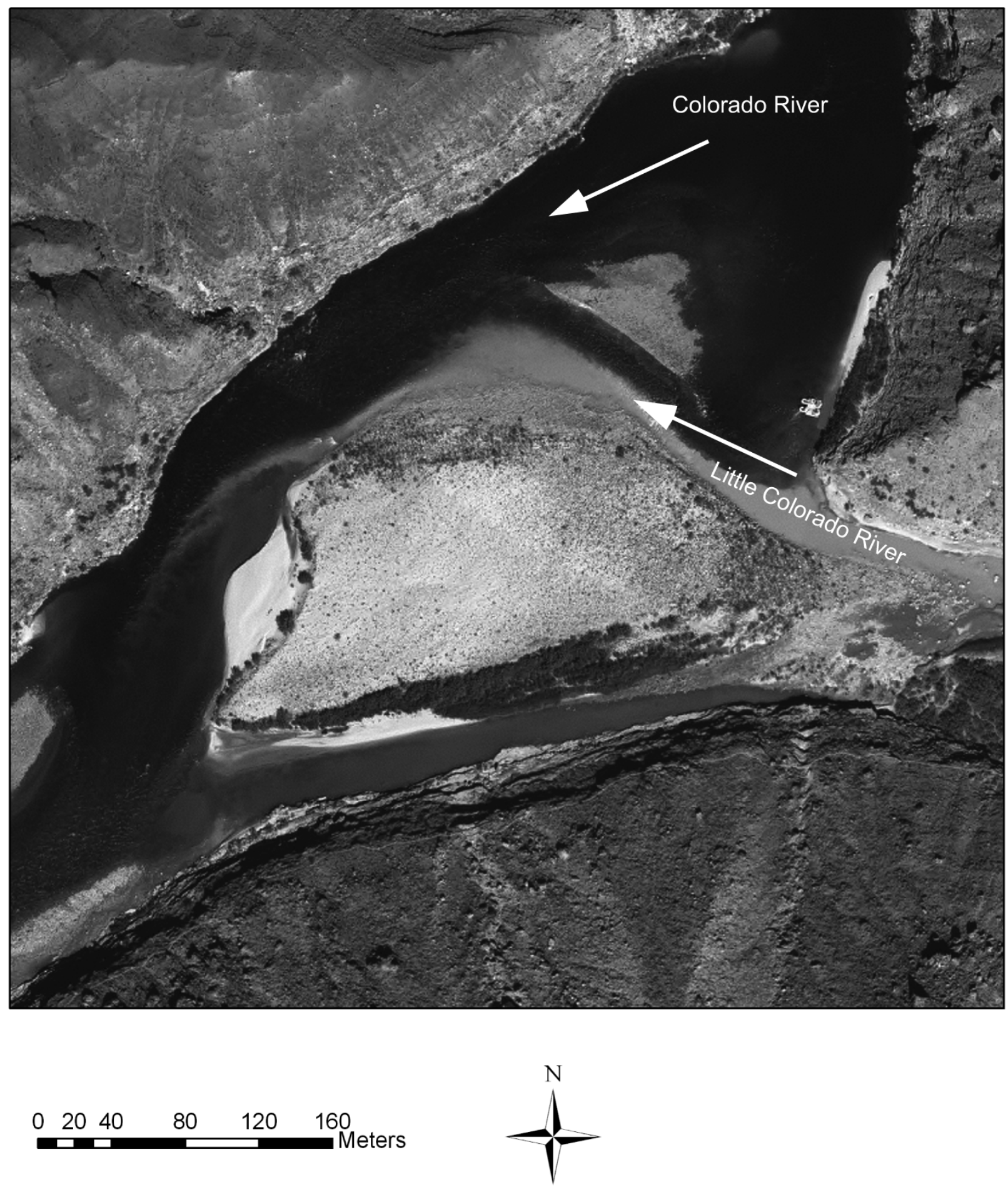

Figure 2. Aerial black and white digital imagery from September 2000 of the confluence area of the Colorado River and the Little Colorado River taken when mainstem discharge was $226 \mathrm{~m}^{3} / \mathrm{s}$ (U.S. Geological Survey, 2000). Arrows indicate the direction of flow. The suspended sediment coming from the Little Colorado River (lighter color) illustrates the path that water from the Little Colorado River can take when the mainstem is at low discharge. 


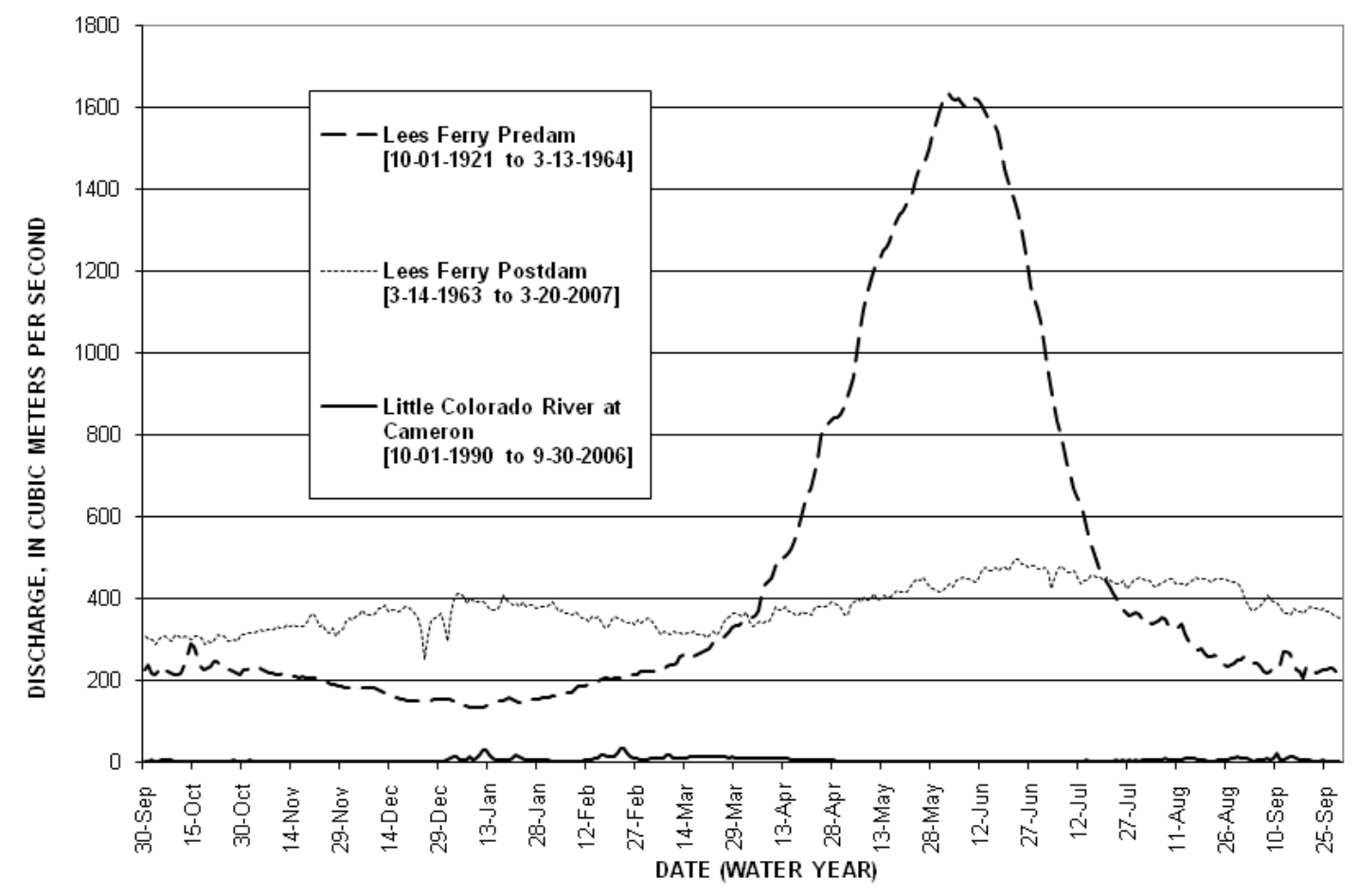

Figure 3. Line graph contrasting the predam (dashed line) and postdam (dotted line) mean daily discharge of the Colorado River, compared with the discharge pattern of the Little Colorado River (solid line). Maximum daily discharges from the Colorado River have shifted from the months of April through July in the predam era to the months of June through August in the postdam era. Discharges from the Little Colorado River are greatest from late January through April. Discharge reported in $\mathrm{m}^{3} / \mathrm{s}$.

Options for ameliorating Glen Canyon Dam effects on the survivorship of young fish entering the Colorado River from the LCR include altering water volume and(or) constraining the daily range of the releases. To gain a better understanding of how Glen Canyon Dam release volumes affect low velocity, warmwater environments at the confluence interface, we georeferenced topographic, bathymetric, velocity, and thermal data measurements to quantify the areal extent of these environments available for postlarval YOY humpback chub (30-90 mm TL) under four Colorado River discharges $\left(227,368,538\right.$ and $\left.878 \mathrm{~m}^{3} / \mathrm{s}\right)$ and the LCR at base flow $(6.3$ $\mathrm{m}^{3} / \mathrm{s}$ ). The LCR historically remains at base flow for extended periods of time during early growth and development of humpback chub (U.S. Geological Survey, 2010; May-July, fig. 3). We focused on older YOY humpback chub because these fish have achieved larger sizes, have increased morphological and sensory capabilities, and are less prone to passive drift than the larval life stages and therefore can actively select habitats.

\section{Study Area}

The confluence study area included $760 \mathrm{~m}$ of the Colorado River, linear distances approximately $300 \mathrm{~m}$ upstream of the LCR mouth and $460 \mathrm{~m}$ downstream of the cobble island, and the lowermost $280 \mathrm{~m}$ of the LCR (fig. 2). The Colorado River portion of the study area was limited 
to the area where warmwater influence from the LCR could not be distinguished from mainstem temperatures (fig. 2). The LCR confluence with the Colorado River is located in Grand Canyon, Arizona, approximately 124 km downstream from Glen Canyon Dam (fig. 1).

The LCR empties into the Colorado River from the east as the mainstem flows in a southerly direction (fig. 2). At the confluence, there is a large (350 m x $170 \mathrm{~m})$ island that affects the hydraulics of the mainstem and consequently impacts the availability of warmwater, lowvelocity environments. This island is composed of sand, cobble and boulders, is well armored, and does not shift in position. The availability of the confluence's warmwater, low-velocity environments can vary significantly with discharge volume from either river. The south side of the LCR is formed by Tapeats Sandstone ledges that cause abrupt changes in channel topography, while its north side displays boulder-strewn debris slopes with conglomerate outcroppings that can create variable topographies and microhabitats for fish. Channel substrates of the LCR are primarily travertine-encrusted boulders embedded in silt and silty-sand sediments. The east and west banks of the Colorado River are comprised of steep, boulder-laden debris fans and Tapeats Sandstone ledges. The mainstem channel forms a deep $(14 \mathrm{~m})$ pool approximately $220 \mathrm{~m}$ upstream from the LCR confluence, and then becomes a relatively shallow riffle/pool complex from the confluence to the end of the study area, $680 \mathrm{~m}$ downstream. The mainstem channel substrate in this area is primarily boulders and cobbles.

The LCR was once perennial, but now only flows intermittently throughout most of its 573km corridor (Colton, 1937; Miller, 1946). It is subject to episodic floods after spring thaws and summer rains that drain the $69,870-\mathrm{km}^{2}$ river basin (Colton, 1937). Perennial flows are maintained in the lower $21 \mathrm{~km}$ by spring discharges that cumulatively result in a mean base flow of $6.3 \mathrm{~m}^{3} / \mathrm{s}$ near the mouth (Cooley, 1976). Temperatures of the lower LCR vary seasonally from $5^{\circ} \mathrm{C}$ to $25^{\circ} \mathrm{C}$, while specific conductance usually remains above $4000 \mu \mathrm{S} / \mathrm{cm}$, which are values that are three to five times higher than those found in the Colorado River (U.S. Geological Survey, 2010; Voichick and Wright, 2007). Chute Falls, a travertine dam located $14 \mathrm{~km}$ above the confluence, obstructs fishes from moving further upriver (Kaeding and Zimmerman, 1983; Stone and others, 2007). Before 2003, humpback chub were found in the LCR corridor below Chute Falls, but they were translocated above Chute Falls on August 1, 2003, in order to extend the range of this species (Stone and others, 2007).

\section{Selection of Measured Discharges}

The Colorado River Basin drains one-twelfth of the continental United States. Predam seasonal flow variations were considerable, with median annual discharge recorded at the Lees Ferry gage in Grand Canyon ranging from $141 \mathrm{~m}^{3} / \mathrm{s}$ in fall-winter months to $2,407 \mathrm{~m}^{3} / \mathrm{s}$ during peak runoff in the spring-summer months (Topping and others, 2003). The greatest recorded flood volumes are estimated at 4,813 m³ $/ \mathrm{s}$ in 1921 and 5,947 m³ $/ \mathrm{s}$ in 1884 (Topping and others, 2003). Since regulation began in 1963, median annual discharge has varied between $268 \mathrm{~m}^{3} / \mathrm{s}$ and 450 $\mathrm{m}^{3} / \mathrm{s}$. In 1996, operational constraints were placed on Glen Canyon Dam and the median annual discharge measured at the U.S. Geological Survey gage at Lees Ferry through the year 2000 was $378 \mathrm{~m}^{3} / \mathrm{s}$ (Topping and others, 2003). Discharges from Glen Canyon Dam vary daily to meet the needs of electrical power demand and water delivery, with the greatest volumes released in the summer and winter months (Korman and others, 2004). Since 1996, the range of the daily fluctuations can be up to $226 \mathrm{~m}^{3} / \mathrm{s}$ (U.S. Department of the Interior, 1996). 
Because of the variable width of the canyon (Schmidt and Graf, 1990), changes in discharge volume of $226 \mathrm{~m}^{3} / \mathrm{s}$ per day can translate to as much as a 2-m change in stage elevation in narrower portions and as much as $0.5 \mathrm{~m}$ in wider portions of the mainstem (Hazel and others, 2006). Daily operations from the dam that include $113 \mathrm{~m}^{3} / \mathrm{hr}$ allowable upramp and $42.5 \mathrm{~m}^{3} / \mathrm{hr}$ allowable downramp (U.S. Department of the Interior, 1996) can produce significant and often abrupt changes to the availability of warmwater, low-velocity environments along shorelines. At the confluence area with the LCR, daily changes in mainstem volume can force inflows from the LCR from one side of the confluence island to the other. Because mainstem temperatures at the confluence area generally do not exceed $14^{\circ} \mathrm{C}$, even in the warmest summer months (Voichick and Wright, 2007), the flow volume of the mainstem is a critical variable that affects water velocities at the confluence and the routing of warmer temperature water (up to $25^{\circ} \mathrm{C}$ in June and July; Voichick and Wright, 2007) coming from the LCR. Thus mainstem volumes affect the amount of lowvelocity, warmwater area available for young fish at the LCR confluence.

Based on the operational constraints associated with the Record of Decision (U.S. Department of the Interior, 1996), the discharge volumes of $227,368,538$, and $878 \mathrm{~m}^{3} / \mathrm{s}$ were selected to measure velocity and temperature dynamics of the mainstem and LCR at the confluence area. The lowest of these discharges $\left(227 \mathrm{~m}^{3} / \mathrm{s}\right)$ approaches the allowable minimum base flow from Glen Canyon Dam during the day and is within the range of fluctuations associated with steady discharges from Glen Canyon Dam. The next discharge, $368 \mathrm{~m}^{3} / \mathrm{s}$, is a discharge that approximates the median annual discharge $\left(378 \mathrm{~m}^{3} / \mathrm{s}\right)$ since 1996 . The discharge of $538 \mathrm{~m}^{3} / \mathrm{s}$ is the average maximum discharge since 1996. Lastly, $878 \mathrm{~m}^{3} / \mathrm{s}$ is the maximum discharge available under power operations. Each discharge is a volume that is typically encountered at the study area, and each affects how water from the mainstem and the LCR are routed around the island, thus affecting velocities and temperatures.

\section{Methods}

\section{Data Collection}

Temperature, velocity, and bathymetric data were collected within the study area to determine available low-velocity, warmwater areas using the growth and swimming criteria of YOY and juvenile humpback chub (Bulkley and others, 1981; Converse and others, 1998; Clarkson and Childs, 2000; Robinson and Childs, 2001). Each physical parameter was collected independently and, in some cases, over multiple years (table 1), but a common spatial referencing system was used to merge the data. Specific details of the spatial referencing follow description of the data collection method for each parameter.

Because Glen Canyon Dam operations typically include daily fluctuations, parameters such as temperature had to be measured opportunistically when specific discharges were present at the confluence and when the LCR was not flooding. In the case of the velocity data, a steady flow experiment in the spring and summer of 2000 (Valdez and others, 2000) presented an opportunity to capture data for specific mainstem discharges for the entire study area without interruption. The data sets were merged to determine total available low-velocity, warmwater area at the confluence under the four identified discharges. 
Table 1. Dates associated with temperature, velocity, and bathymetric data capture at the confluence of the Colorado and Little Colorado Rivers.

[Mean temperatures are also identified to show the likely source of water temperatures $\geq 16^{\circ} \mathrm{C}$.]

\begin{tabular}{|c|c|c|c|c|c|}
\hline \multirow[t]{2}{*}{$\begin{array}{c}\text { Colorado River } \\
\text { Discharge } \\
\left(\mathrm{m}^{3} / \mathrm{s}\right)\end{array}$} & \multicolumn{3}{|c|}{ Dates of parameter measurements } & \multicolumn{2}{|c|}{$\begin{array}{l}\text { Mean daily minimum, average, and } \\
\text { maximum temperature values at } \\
\text { confluence area }\left({ }^{\circ} \mathrm{C}\right)\end{array}$} \\
\hline & Temperature & Velocity & Bathymetry & $\begin{array}{c}\text { Colorado River } \\
\text { temperature } \\
\left({ }^{\circ} \mathrm{C}\right)\end{array}$ & $\begin{array}{l}\text { Little Colorado River } \\
\text { temperature }\left({ }^{\circ} \mathrm{C}\right)\end{array}$ \\
\hline $227 \mathrm{~m}^{3} / \mathrm{s}$ & $\begin{array}{l}09 / 05 / 2000 \\
\text { to } \\
09 / 09 / 2000\end{array}$ & $\begin{array}{l}09 / 01 / 2000 \\
\text { to } \\
09 / 09 / 2000\end{array}$ & $\begin{array}{l}03 / 26 / 1996 \\
\text { to } \\
04 / 07 / 1996\end{array}$ & $\begin{array}{l}12.1 \\
12.4 \\
12.8\end{array}$ & $\begin{array}{l}19.6 \\
20.7 \\
22.1\end{array}$ \\
\hline $368 \mathrm{~m}^{3} / \mathrm{s}$ & $\begin{array}{l}05 / 01 / 1993 \\
\text { to } \\
07 / 10 / 1996\end{array}$ & $\begin{array}{l}05 / 25 / 2000 \\
\text { to } \\
06 / 02 / 2000\end{array}$ & $\begin{array}{l}03 / 26 / 1996 \\
\text { to } \\
04 / 07 / 1996\end{array}$ & $\begin{array}{l}10.5 \\
11.2 \\
11.8\end{array}$ & $\begin{array}{l}17.6 \\
21.7 \\
26.0\end{array}$ \\
\hline $538 \mathrm{~m}^{3} / \mathrm{s}$ & $\begin{array}{l}05 / 25 / 2000 \\
\text { to } \\
06 / 02 / 2000\end{array}$ & $\begin{array}{l}05 / 25 / 2000 \\
\text { to } \\
06 / 02 / 2000\end{array}$ & $\begin{array}{l}03 / 26 / 1996 \\
\text { to } \\
04 / 07 / 1996\end{array}$ & $\begin{array}{l}11.7 \\
12.2 \\
12.8\end{array}$ & $\begin{array}{l}17.6 \\
20.1 \\
23.5\end{array}$ \\
\hline $878 \mathrm{~m}^{3} / \mathrm{s}$ & $\begin{array}{l}09 / 01 / 2000 \\
\text { to } \\
09 / 09 / 2000\end{array}$ & $\begin{array}{l}09 / 01 / 2000 \\
\text { to } \\
09 / 09 / 2000\end{array}$ & $\begin{array}{l}03 / 26 / 1996 \\
\text { to } \\
04 / 07 / 1996\end{array}$ & $\begin{array}{l}10.6 \\
11.4 \\
11.6\end{array}$ & $\begin{array}{l}19.6 \\
20.7 \\
22.1\end{array}$ \\
\hline
\end{tabular}

\section{Suitable Habitats of YOY Humpback Chub}

To establish suitable depths and velocities for YOY humpback chub (30-90 mm TL) in the LCR confluence, we examined the fish-habitat data from the LCR collected by the U.S. Fish and Wildlife Service and from the literature. The Fish and Wildlife Service conducted 14 sampling trips in the LCR from June 1992 to May 1995, during which biologists deployed unbaited hoop nets at intervals of 3-4 m across the river by fastening them to ropes anchored to opposing stream banks (Gorman and Stone, 1999; Stone and Gorman, 2006). They captured a total of 8,373 YOY humpback chub (30-90 mm TL) in 1,438 of the 5,446 hoop nets deployed, at a median depth of 105 $\mathrm{cm}$ and median current velocity of $0.180 \mathrm{~m} / \mathrm{s}$ (U.S. Fish and Wildlife Service, unpub. data). Converse and others (1998) found juvenile chub (105-150 mm TL) associated with velocities of 0.1 $\mathrm{m} / \mathrm{s}$ in talus shorelines and $0.2 \mathrm{~m} / \mathrm{s}$ in debris fan, sandbar, and vegetated shorelines. Lastly, Bulkley and others (1981) determined that humpback chub (30-100 mm TL) maintained cruising speeds at $0.1-0.2 \mathrm{~m} / \mathrm{s}$ and sustained swimming speeds of $0.2-0.4 \mathrm{~m} / \mathrm{s}$. On the basis of these data sources, we used depths $\leq 1 \mathrm{~m}$ and velocities $\leq 0.2 \mathrm{~m} / \mathrm{s}$ to delineate suitable habitats at the LCR confluence for YOY humpback chub (30-90 mm TL).

Establishment of the lower thermal requirement for YOY humpback chub was based on growth studies done by Bulkley and others (1981) in the lab and by Clarkson and Childs (2000) and Robinson and Childs (2001) in the field. The growth of YOY humpback chub is significantly correlated with increasing water temperature (Clarkson and Childs, 2000; Robinson and Childs, 2001). Final thermal preferendum for humpback chub was determined to be $24^{\circ} \mathrm{C}$ (Bulkley and others, 1981), but fish growth is measureable when water temperatures range between $14^{\circ} \mathrm{C}$ and $20^{\circ} \mathrm{C}$ (Clarkson and Childs, 2000). Using a linear equation of Robinson and Childs (2001) for growth and temperature, we identified a lower thermal limit of $16^{\circ} \mathrm{C}$ for acceptable YOY humpback chub growth. At this temperature, YOY humpback chub should grow approximately 0.2 $\mathrm{mm} /$ day. 


\section{Temperature Data}

The collection of temperature data spanned a 4-year period because of fluctuating dam operations (table 1). Two approaches for water-temperature data collection were used in this study.

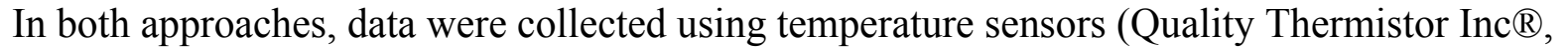
Boise, Idaho) with an associated accuracy of $\pm 0.1^{\circ} \mathrm{C}$ and thermal range of $0^{\circ} \mathrm{C}$ to $100^{\circ} \mathrm{C}$. First, stationary temperature sensors connected to data loggers were used to pinpoint mainstem discharges that shifted the warmer water of the LCR from one side of the confluence island to the other. Because mean mainstem temperatures from 1990 through 2007 at river kilometer 124 were $10.6 \pm 1.7^{\circ} \mathrm{C}$ standard deviation (Voichick and Wright, 2007), and daily temperatures did not exceed $13^{\circ} \mathrm{C}$ during the months of June through August between the years 1996-2000 (table 1; Voichick and Wright, 2007), temperatures that registered greater than $13^{\circ} \mathrm{C}$ were presumed to be sourced from the LCR. To collect baseline data at the upstream end of the confluence island, a series of thermistors were placed perpendicular to flow on the river bottom at the upper end of the confluence island. Each thermistor was connected to a data recorder (Campbell Scientific ${ }^{\circledR}-\mathrm{CR} 10$ ) set to record each minute. Five 1-minute readings were averaged and recorded along with a date and time stamp. Temperature readings were correlated with mainstem and LCR discharge by timestamp correlation with pressure transducers and USGS gage data located at river kilometer 123.5 below the dam, approximately $0.5 \mathrm{~km}$ upstream of the confluence (fig. 4).

In order to cover the spatial extent beyond those recorded by the stationary therimistors within the study area, handheld and boat-mounted thermistors were also used. These temperature data points were spatially referenced using a total station data collector. To collect nearshore temperature data in areas where it was shallow enough to wade, thermistors were fastened $0.10 \mathrm{~m}$ above the bottom of survey prism poles. Surveyors took measurements on a 5-meter grid running perpendicular to river flows. Grid limits were defined by shoreline and uniform cold-temperature limits $\left(12^{\circ} \mathrm{C}\right)$ along the south, west, and north sides of the island. Temperature readings were radioed to the survey instrument operator who entered the readings as attribute information for each position into the total station data collector. To collect temperature in deeper, offshore areas greater than $1 \mathrm{~m}$ deep, thermistors were fastened to a 5-m-long prism pole that was sleeve-mounted on the front of a 14-ft motorized raft capable of holding position against river currents. A cluster prism was used on the top of this pole to allow easier tracking and acquisition of distance readings by the total station operator. The boat held position long enough for the thermistor reading to stabilize and for the total station operator to acquire the shot. The temperature reading was radioed to the operator for entry into the total station data collector. Figure 4 illustrates the transect lines where stationary themistors were deployed and the polygon areas where thermal data were collected by wading and by boat sampling. 

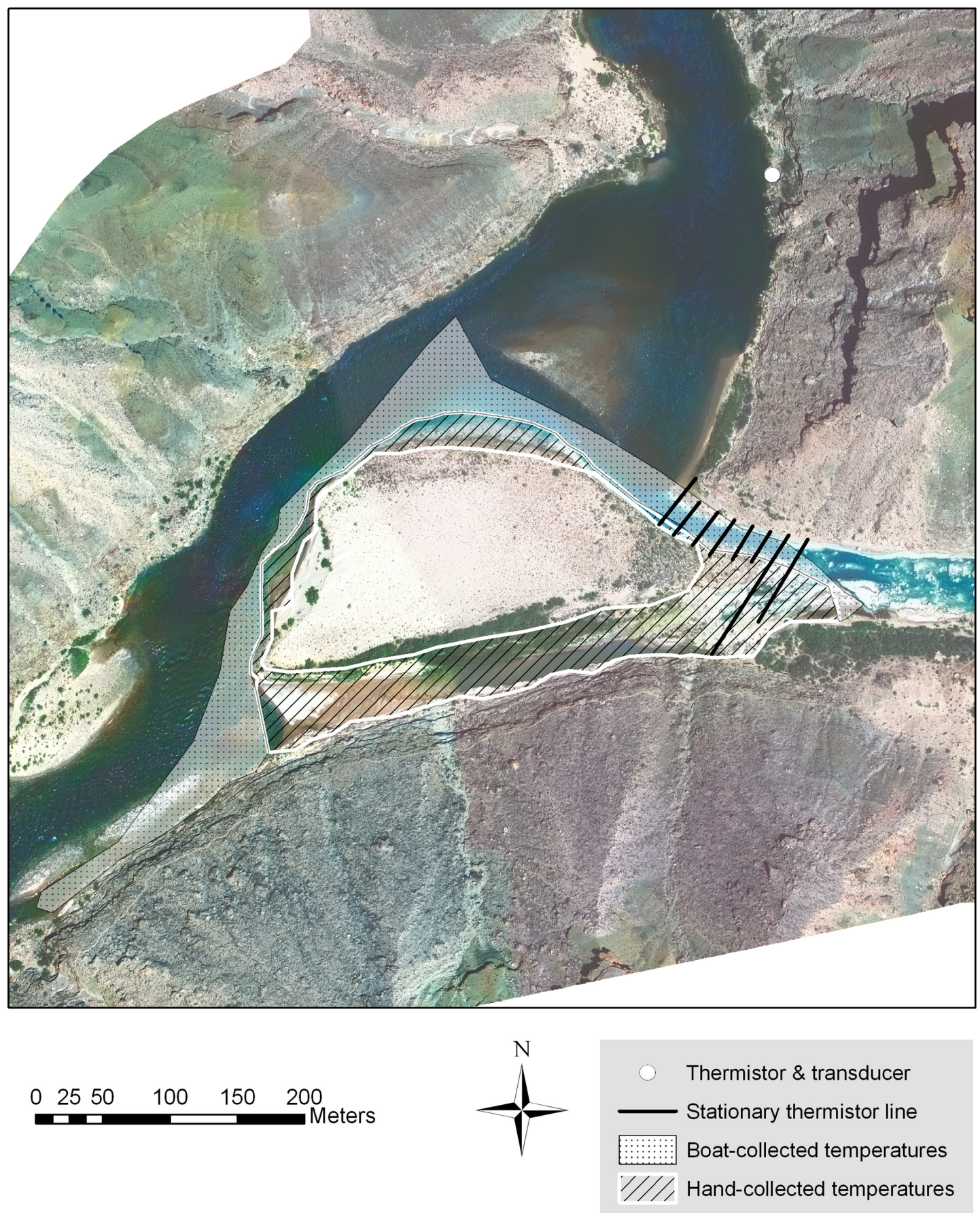

Figure 4. Illustration showing where water temperature data were collected in the study area. Aerial color digital satellite image of the Little Colorado River confluence area taken in May 2002 (USGS photo, 2002), when the Colorado River was at $226 \mathrm{~m}^{3} / \mathrm{s}$ discharge and the LCR was at base flow, $6.3 \mathrm{~m}^{3} / \mathrm{s}$. See figure 2 for flow direction for the Little Colorado and Colorado Rivers. 
These data were correlated with terrestrial and offshore topography to compile a complete thermal picture over the confluence area for a given mainstem discharge. The flow-matched data files were imported into SpectraPrecision (Westminster, Colo.) TerraModel ${ }^{\odot}$ v10.3 graphic presentation and analysis software. TerraModel ${ }^{\odot}$ software uses point data to construct contours with a triangulated irregular network (TIN) models that incorporate splines in its mathematics to create the contours. Contours at $1{ }^{\circ} \mathrm{C}$ were developed by using the horizontal position of each temperature location as the "X-Y" position and the vertical position within the software equaling the temperature reading for each time stamp. Warmwater areas (between $12^{\circ} \mathrm{C}$ and $25^{\circ} \mathrm{C}$ ) were contoured and summed for different temperature ranges at each mainstem discharge.

\section{Velocity Data}

Steady flow discharges during the summer of 2000 allowed water velocities to be measured throughout the confluence region for four discharge volumes $\left(227,368,504\right.$, and $\left.878 \mathrm{~m}^{3} / \mathrm{s}\right)$. The four steady discharges from Glen Canyon Dam were maintained for periods that were long enough (ca. $16 \mathrm{hrs)}$ to collect the entire velocity picture at the confluence study area. The constant discharge eliminated the need for the serial data collection efforts used in the temperature measurement component.

Current velocity data were collected using both hand-held velocity meters and a 3-MHz broadband Acoustic Doppler (ADP) instrument that measures water vector speeds and direction. The ADP had a velocity range of $\pm 10 \mathrm{~m} / \mathrm{s}$, resolution of $0.01 \mathrm{~m} / \mathrm{s}$, accuracy of $0.05 \mathrm{~m} / \mathrm{s}$, and a profiling range of 3-6 m (RiverSurveyor ADPC, Sontek/YSI, Inc., San Diego, Calif.) and was used for areas only accessible by boat (too deep to wade). Positions were referenced to network control using backpack-mounted real-time kinematic global positioning system (RTK GPS) receivers. In areas shallow enough to wade, a hand-held velocity meter was rotated and lifted through the water column (1-m depth) to yield the maximum velocity at each data collection point. The same transect lines that were established for hand-held temperature measurements were used for velocity measurements. Because the intent of the study was to determine velocities greater than $0.2 \mathrm{~m} / \mathrm{s}$ or less than $0.2 \mathrm{~m} / \mathrm{s}$, samples recorded maximum velocities at a point within the sample space. The survey technicians would hold the instrument in position long enough to have stable readings, then record the velocity magnitude as an attribute within the RTK data collector. The time required for a stabilized reading varied by point.

A boat was used in deeper areas, where the RTK GPS and a laptop computer with Coastal

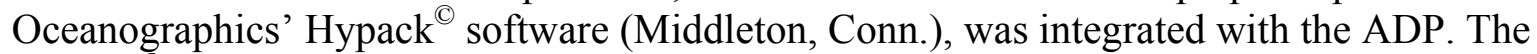
Hypack $^{\mathbb{C}}$ software time tagged the velocity data and assigned each point a discrete position. With this instrument, velocity readings were collected in $0.5-\mathrm{m}$ segments and averaged over the depth of the water column before being recorded to the hard disk of the computer. One-second updates from the RTK GPS system allowed boat velocity to be compensated for in determining current speed and direction.

We used the TerraModel ${ }^{\odot}$ software package to graphically represent the measured stream velocities in and around the confluence area in order to define suitable habitat availability for YOY humpback chub. Measured mainstem velocities at the LCR confluence ranged from 0 to $4.2 \mathrm{~m} / \mathrm{sec}$, depending on discharge rates from Glen Canyon Dam and in the absence of spring runoff or storm spates from the LCR. 


\section{Bathymetric Data}

Bathymetric data were collected at the confluence area during the Beach Habitat Building Flow in March 1996 (table 1; Webb and others, 1999). The 1,274- $\mathrm{m}^{3} / \mathrm{s}$ sustained discharge provided enough water depth (greater than $1.5 \mathrm{~m}$ ) at the confluence to allow full boat access and sonar measurements in the confluence area. Bathymetric data were collected using Hypack@ rangeazimuth and sonar techniques. A boat-mounted, single beam transducer powered by a $200-\mathrm{kHz}$ Marimatech echo sounder with a 2-degree narrow beam and depth of operation to $100 \mathrm{~m}$ (Hinnerup, Denmark) was connected to a multiport computer (see Kaplinski and others, 2009, for more details). Horizontal positions were referenced to network control by way of a radio-linked shore station that sent time-tagged range and azimuth data to the shipboard computer. The Hypack $($ software combined depth information from the echo sounder with position data in real time (Kaplinski and others, 2009). This system allowed for planned track lines and real-time positions and depths to ensure complete river bottom coverage. For the current study, we assumed that the channel and confluence bathymetry had not changed significantly in the 4 years since the sampling occurred in 1996. This assumption was based on the geology of the confluence area, the lack of any mainstem experimental flood events, and the fact that the LCR did not have any substantial flood events in that time period.

\section{Spatial Referencing}

A common spatial referencing system was used to merge the temperature, bathymetric, and velocity data. The digital imagery and digital elevation model (DEM), survey control, temperatures, velocities, and bathymetry are referenced to the National Spatial Reference System (NSRS, managed by National Geodetic Survey, National Oceanic and Atmospheric Administration). A base map of the confluence area was created using a mixture of mapping technologies. Aerial digital imagery of the Colorado River Ecosystem was collected by ISTAR Americas, Inc. (Herndon, Va.) in 2002 and used to create a 1-m DEM. Simultaneous, dualfrequency GPS data were collected at the confluence control stations and at published NSRS control stations along the Colorado River canyon rim, and these were combined with networkadjusted total station measurements (for example, correctional errors associated with instrument heights, translated coordinate numbers, or other inconsistencies) to create accurate project control. Conventional total station (range-azimuth) measurements were used to establish higher resolution topographic base data within the vertical operating limits of each river and were substituted for the digital imagery DEM in areas of overlap. The limits for these total station measurements extended from approximately waist-deep in each river to approximately $4 \mathrm{~m}$ above each river's water surface. The off-shore bathymetry data were combined with the terrestrial map to create a threedimensional surface of the confluence from the river bottom to approximately $30 \mathrm{~m}$ above the rivers, corresponding to the mainstem predam high-water elevation.

The resulting surface model provided the base map, which encompassed the entire stage range for locating results of temperature and velocity measurements. Postprocessing and network adjustment of multiple, independent vectors using Trimble Geomatics Office (Sunnyvale, Calif.) resulted in network accuracies for project control of $2 \mathrm{~cm}$ horizontally and $5 \mathrm{~cm}$ vertically at 95percent confidence. DEM accuracy is within $30 \mathrm{~cm}$ vertically, and digital imagery accuracy is within $15 \mathrm{~cm}$ horizontally (95 percent) at the confluence region. 


\section{Results}

\section{Physical Parameter Delineation}

The use of land survey instruments and techniques worked well to develop accurate, spatially referenced data points for water temperature measurements and for the hand-held velocity measurements. The broad-band ADP experienced extreme noise in the recorded data when transitioning over depths that exceeded a 6-m difference. This may have been a result of the limitations of the instrument and its profiling range, which was 3-6 $\mathrm{m}$. Transitions from low suspended solids and waters low in salinity concentrations from the mainstem to higher values from the LCR also resulted in poor data readings. Exposing the ADP to relatively turbulent flows, found over much of the mainstem within the study area, also resulted in noisy data. As a result, much of the broad-band ADP data were unusable. The hand-held velocity meter was used to supplement noisy doppler instrument readings where large expanses of river did not have clear doppler readings. Because this study was focused on defined velocity and temperature parameters, the velocity data reported here are only those that are $\leq 0.2 \mathrm{~m} / \mathrm{s}$ and $\leq 1 \mathrm{~m}$ in depth, represented by polygon areas in figure 4.

\section{Available Ponded Area}

Polygon areas of suitable velocity and temperatures are identified separately for each measured discharge (figs. 5-7). Color banding and $1{ }^{\circ} \mathrm{C}$ contours were used to display specific temperature ranges found within the confluence area. Because the mainstem water temperatures remain below the $16^{\circ} \mathrm{C}$ limit during most times of the year, the amount of available low-velocity area was greater than the amount of available low-velocity, warmwater area (table 2).

At mainstem discharge of $227 \mathrm{~m}^{3} / \mathrm{s}, 0.20$ ha of slow, warmwater environments are available and restricted to the LCR and a thin stream of warm LCR current running along the north side of the island (figs. $5 A, B$; table 2). Most of the warm current stream exceeds the YOY velocity tolerance of $0.2 \mathrm{~m} / \mathrm{sec}$ (fig. $5 A$ ). The channel running along the south or "left" side of the island is virtually dry at this mainstem river stage.

The availability of low-velocity areas increases from 1.12 hectare (ha) to 1.79 ha (table 2) at mainstem discharges of $368 \mathrm{~m}^{3} / \mathrm{s}$, and the area of low-velocity, warm water increases by more than 500 percent from 0.20 ha to 1.23 ha (table 2 , figs. $6 A, B$ ). The downstream interface of the south channel with the mainstem also creates a region of low velocity $(0.2 \mathrm{~m} / \mathrm{s})$ that can provide YOY with the opportunity to swim back into the warmer LCR and avoid the colder and faster mainstem currents (figs. $6 A, B$ ). At this mainstem discharge a warmwater stream runs along the north side of the island, though most of this stream has velocities above the $0.2-\mathrm{m} / \mathrm{s}$ tolerance limit for YOY humpback chub (figs. $6 A, B$ ). 
Table 2. Available low-velocity $(0.2 \mathrm{~m} / \mathrm{s})$ area and low-velocity, warmwater area $\left(0.2 \mathrm{~m} / \mathrm{s}, \geq 16^{\circ} \mathrm{C}\right)$ associated with four mainstem discharges at the Little Colorado River confluence.

[Also shown are positive and negative changes in area (ha, and percent change) in low-velocity and low-velocity warm water for a discharge, as well as changes in low velocity, warmwater areas between discharges. Area is reported in hectares (ha).]

\begin{tabular}{|c|l|l|l|l|}
\hline $\begin{array}{c}\text { Colorado } \\
\text { River } \\
\text { Discharge } \\
\left(\mathbf{m}^{3} / \mathbf{s}\right)\end{array}$ & $\begin{array}{c}\text { Available low } \\
\text { velocity }(\mathbf{0 . 2} \\
\mathbf{m} / \mathbf{s}) \text { area (ha) }\end{array}$ & $\begin{array}{c}\text { Available warm } \\
\text { water }\left(\mathbf{2} 6^{\circ} \mathbf{C}\right), \text { low } \\
\text { velocity }(\mathbf{0 . 2} \mathbf{m} / \mathbf{s}) \\
\text { area }(\mathbf{h a})\end{array}$ & $\begin{array}{c}\text { Difference in area (ha) and } \\
\text { percent change between low- } \\
\text { velocity areas and low- } \\
\text { velocity, warmwater areas for } \\
\text { a discharge }\end{array}$ & $\begin{array}{c}\text { Area (ha) and percent change } \\
\mathbf{+} /- \text {-) between successive } \\
\text { discharges of low-velocity, } \\
\text { warm environments }\end{array}$ \\
\hline 227 & 1.12 & 0.20 & $-0.92(82 \%$ decrease $)$ & - \\
\hline 368 & 1.79 & 1.23 & $-0.56(31 \%$ decrease $)$ & +1.03 ha $(515 \%$ increase $)$ \\
\hline 538 & 0.42 & 0.02 & $-0.40(100 \%$ decrease $)$ & -1.21 ha $(98 \%$ decrease $)$ \\
\hline 878 & 0.13 & 0.0 & $-0.13(100 \%$ decrease $)$ & $-0.02(100 \%$ decrease $)$ \\
\hline
\end{tabular}

$A$

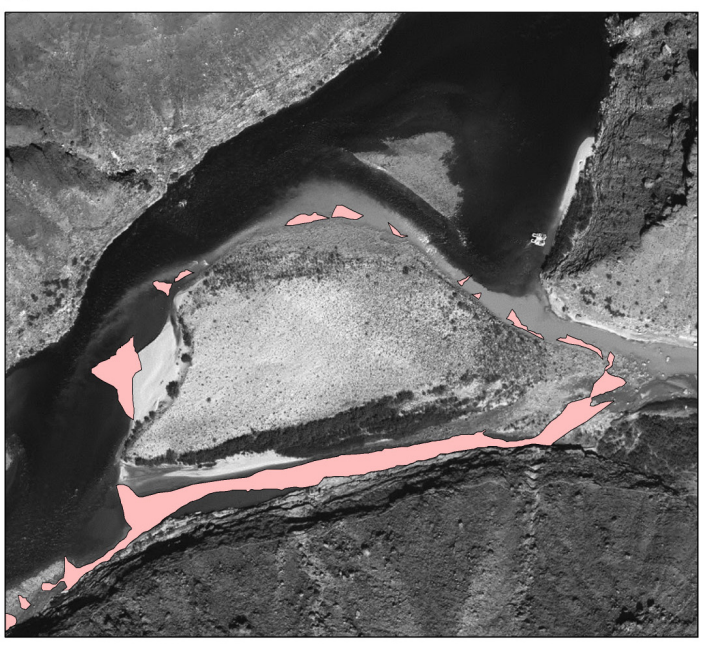

\begin{tabular}{lrrr}
$0 \quad 25 \quad 50 \quad 100 \quad 150 \quad 200$ \\
\hline
\end{tabular}
$B$

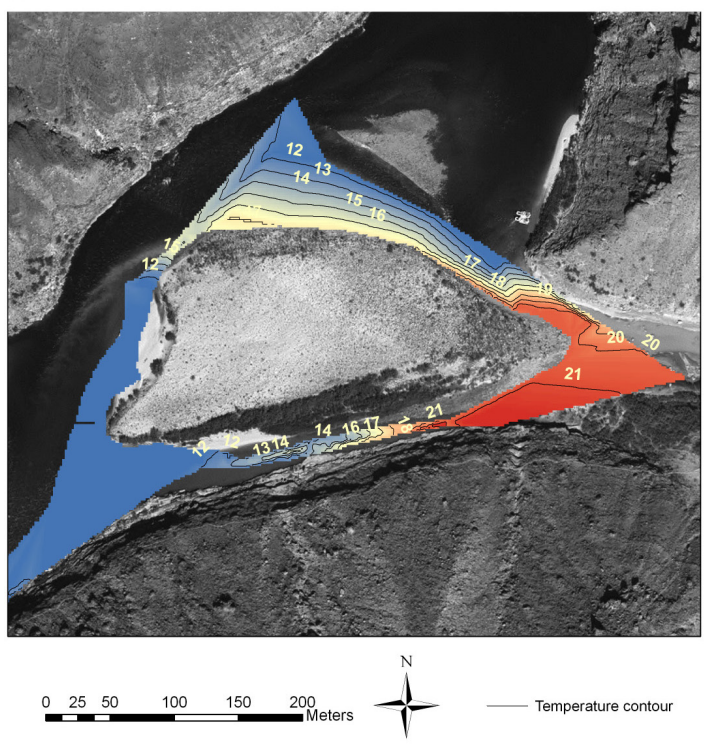

Figure 5. Side-by-side figures of the confluence study area when mainstem discharge is $227 \mathrm{~m}^{3} / \mathrm{s}$ and LCR discharge is at base flow $\left(6.3 \mathrm{~m}^{3} / \mathrm{s}\right)$. A, Available low velocity areas $(0.2 \mathrm{~m} / \mathrm{s}$ and depths less than $1 \mathrm{~m})$ shown in pink polygons, with lowest velocities are on the south portion of the island, along the northern perimeter and in pockets along the western side of the island. $B, 1^{\circ} \mathrm{C}$ temperature contours shown in a graduated color scheme delineating water temperature from $12^{\circ} \mathrm{C}$ (darkest blue color) to $21^{\circ} \mathrm{C}$ (red color). Warmest temperatures are near the mouth of the Little Colorado River and along the north side of the island. The data are overlaid on aerial black and white digital imagery of the confluence of the Colorado and Little Colorado Rivers from September 2000 at mainstem discharge rate of 226 m³/s (USGS photo, 2000). See figure 2 for flow direction for the Little Colorado and Colorado Rivers. 
$A$
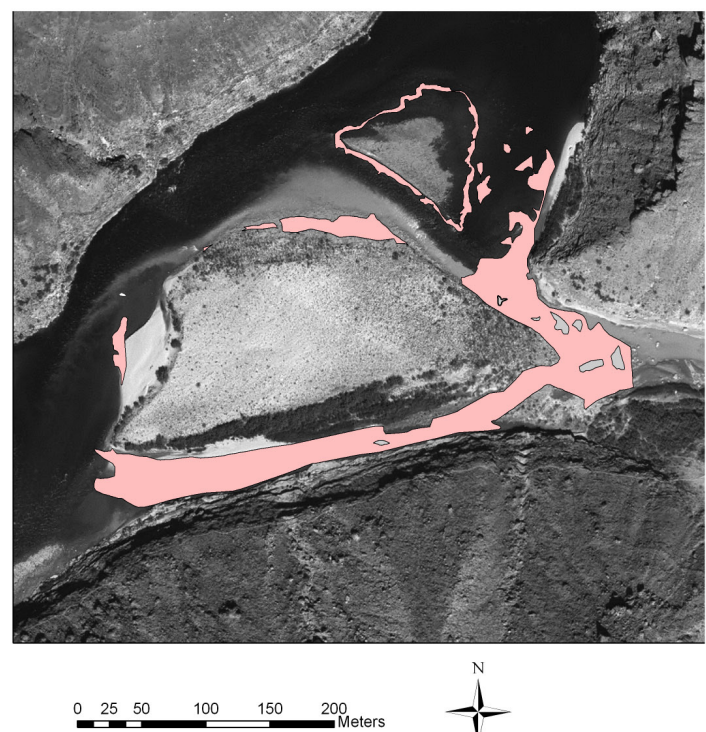

$B$

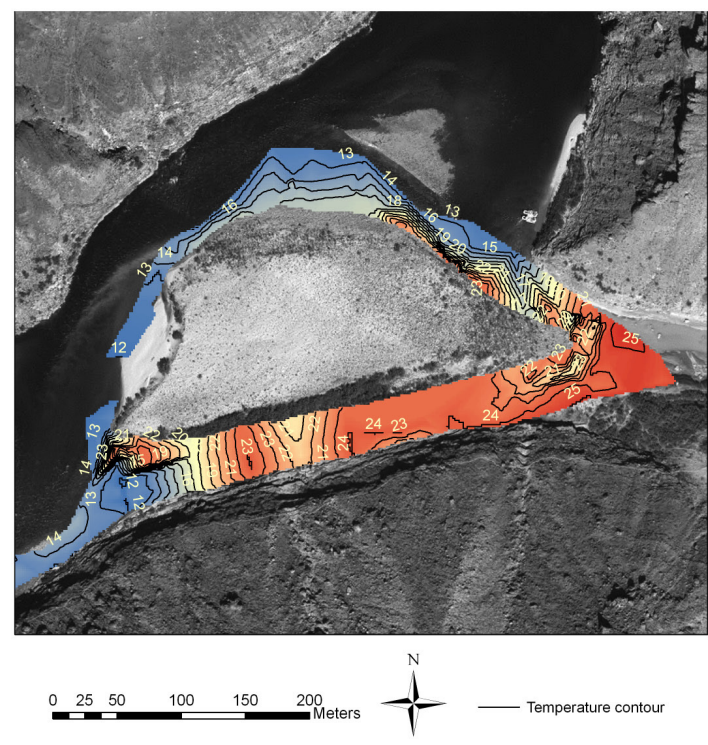

Figure 6. Side-by-side figures of the confluence study area when mainstem discharge is $368 \mathrm{~m}^{3} / \mathrm{s}$ and LCR discharge is at base flow $\left(6.3 \mathrm{~m}^{3} / \mathrm{s}\right)$. A, Available low velocity areas $(0.2 \mathrm{~m} / \mathrm{s}$ and depths less than $1 \mathrm{~m})$ shown in pink polygons, with the lowest velocities primarily found on the south portion of the island and along the upper third of the northern side of the island. $B, 1^{\circ} \mathrm{C}$ temperature contours shown in a graduated color scheme delineating water temperature from $12^{\circ} \mathrm{C}$ (darkest blue color) to $25^{\circ} \mathrm{C}$ (red color). Warmest temperatures are near the mouth of the Little Colorado River and along the south side of the island. The data are overlaid on aerial black and white digital imagery of the confluence of the Colorado and Little Colorado Rivers from September 2000 at mainstem discharge rate of 226 m3/s (USGS photo, 2000). See figure 2 for flow direction for the Little Colorado and Colorado Rivers.

Mainstem discharges greater than $368 \mathrm{~m}^{3} / \mathrm{s}$ force LCR base flows to back up further into the LCR mouth, eventually eliminating all LCR flow around the right (north) side of the island. Temperature data from the stationary thermistors and waded perimeter established that the warmwater plume of LCR water that flows around the right (north) side of the island is available at discharges as high as approximately $396 \mathrm{~m}^{3} / \mathrm{s}$ (F.R. Protiva, unpublished data). Velocities along this plume exceeded the velocity criteria used for YOY chub in this study. At this discharge (396 $\left.\mathrm{m}^{3} / \mathrm{s}\right)$, there is a sharp transitional velocity boundary that corresponds to warm $\left(18^{\circ} \mathrm{C}\right)$ and cold environments $\left(12^{\circ} \mathrm{C}\right)$ (F.R. Protiva, unpublished data), which is also apparent at the $538 \mathrm{~m}^{3} / \mathrm{s}$ discharge (figs. $7 A, B$ ). At the mainstem discharge of $538 \mathrm{~m}^{3} / \mathrm{s}$, colder mainstem water flows around the upper end of the island, encroaches on the ponded areas, and flows through the south channel (fig. 7A). The change in mainstem flow around the island results in a 98-percent reduction in available warmwater, low-velocity area from 1.23 ha to 0.02 ha (table 2 , figs. $7 A, B$ ). When discharges reach maximum power-plant capacity of $878 \mathrm{~m}^{3} / \mathrm{s}$, there are no longer any low-velocity, warm areas at the confluence and the only areas that meet low-velocity, warmwater criteria are in the LCR. 
$A$
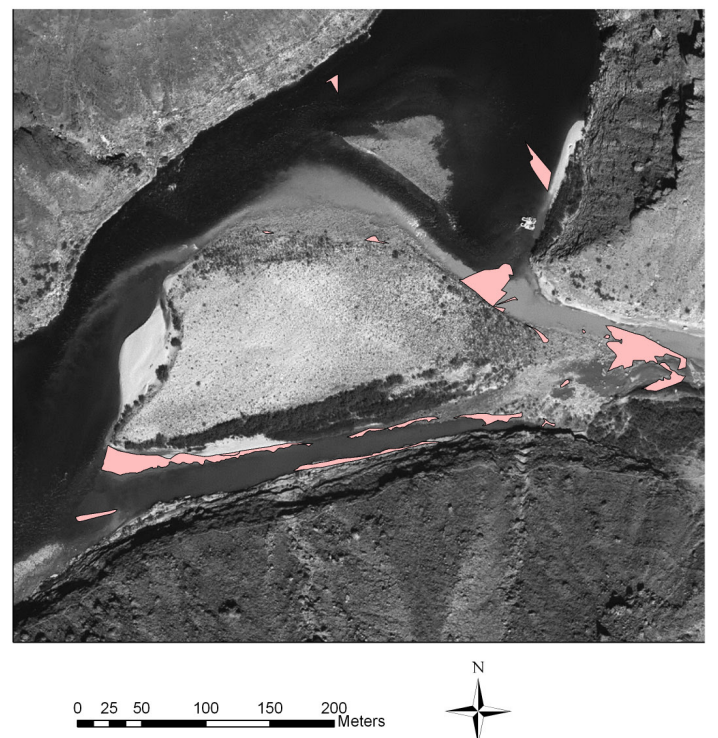

$B$

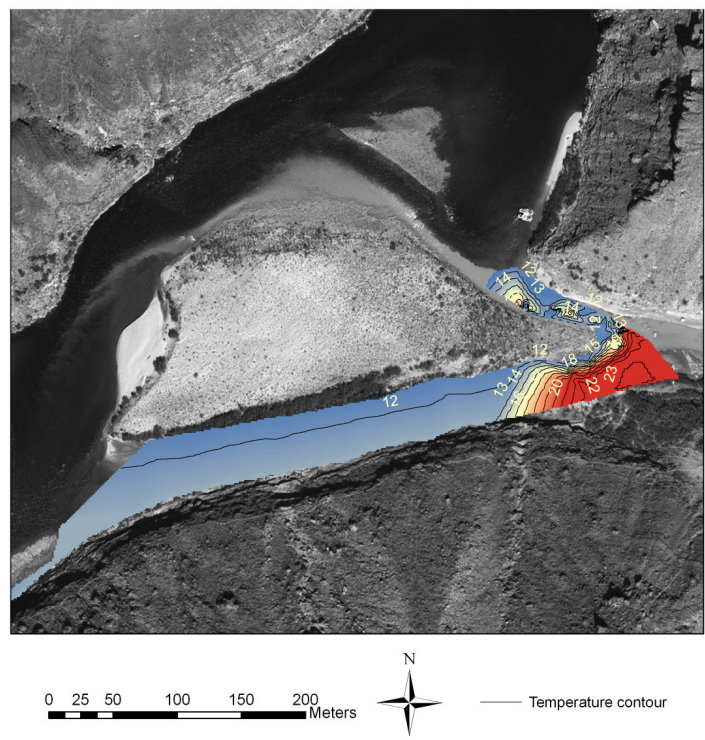

Figure 7. Side-by-side figures of the confluence study area when mainstem discharge is $538 \mathrm{~m}^{3} / \mathrm{s}$ and LCR discharge is at base flow $\left(6.3 \mathrm{~m}^{3} / \mathrm{s}\right)$. A, Available low velocity areas $(0.2 \mathrm{~m} / \mathrm{s}$ and depths less than $1 \mathrm{~m})$ shown in pink polygons, with lowest velocities at the mouth of the LCR, along the northern portion of the island, and in small areas near the southern tip of the cobble island. $B$, Graduated color scheme with $1^{\circ} \mathrm{C}$ temperature contours delineating water temperature from $12^{\circ} \mathrm{C}$ (darkest blue color) to $23^{\circ} \mathrm{C}$ (red color). Warmest temperatures are restricted to the mouth of the Little Colorado River. The data are overlaid on aerial black and white digital imagery of the confluence of the Colorado and Little Colorado Rivers from September 2000 at mainstem discharge rate of $226 \mathrm{~m}^{3} / \mathrm{s}$ (USGS photo, 2000). See figure 2 for flow direction for the Little Colorado and Colorado Rivers.

\section{Discussion}

Altering the pattern and timing of dam releases is a primary mechanism available to resource managers to remedy habitat loss in regulated rivers (Poff and others, 1997; Webb and others, 1999; Patten and Stevens, 2001; Poff and others, 2010). The Biological Opinion for endangered humpback chub in Grand Canyon (U.S. Fish and Wildlife Service, 1995) required the U.S. Bureau of Reclamation to implement a series of experimental flows from Glen Canyon Dam to benefit native fish species. An operational hydrograph that included spring releases up to powerplant capacity $\left(878 \mathrm{~m}^{3} / \mathrm{s}\right)$ and low, steady summer flows $\left(226 \mathrm{~m}^{3} / \mathrm{s}\right)$ was implemented in the year 2000 (Valdez and others, 2000). A hypothesis associated with this hydrograph was that high, sustained discharges in the spring would result in tributary ponding that would elicit prespawning staging and create low-velocity, warmer temperature environments for emerging YOY. This hypothesis was based on the assumption that predam high flows in spring possibly served as a cue for fish spawning (Robinson and others, 1998; Valdez and Hoffnagle, 1999). By returning a sustained high discharge to the annual hydrograph, Valdez and others (2000) hypothesized that YOY retention and subsequent recruitment might be greater compared to years in which tributaries were not ponded. 
Before regulation, discharge data indicate spring ponding associated with mainstem discharges that averaged $2,407 \mathrm{~m}^{3} / \mathrm{s}$ (Topping and others, 2003) could encompass several hectares at the LCR confluence and upstream into the LCR (Howard and Dolan, 1981). Measurements made from photographs of high-water elevations from a 1983 Glen Canyon Dam spillway discharge event $\left(2,605 \mathrm{~m}^{3} / \mathrm{s}\right)$ estimated a warmwater pool area of 3.7 ha (F.R. Protiva, unpublished data). But these discharges exceed power plant capacity $\left(878 \mathrm{~m}^{3} / \mathrm{s}\right)$ by 196 percent and cannot be achieved under regulation except in emergency spill situations. The results from the current study suggest that sustained releases that are less than $400 \mathrm{~m}^{3} / \mathrm{s}$ support low-velocity, warmwater areas at the confluence area, while greater discharges, including those implemented in May 2000 (for example, $878 \mathrm{~m}^{3} / \mathrm{s}$; Valdez and others, 2000) result in a reduction of these areas at the confluence. Higher discharges also increased the extent of colder water temperatures at the mouth of the LCR because the mainstem temperatures in the spring remain at or below $12^{\circ} \mathrm{C}$, particularly with high-volume discharges (table 1; Voichick and Wright, 2007).

Korman and others (2004) identified similar patterns of reduced low-velocity shoreline areas downstream of the LCR with increasing mainstem discharges. They concluded that the greatest areas of low-velocity shoreline were associated with discharges greater than $226 \mathrm{~m}^{3} / \mathrm{s}$ and less than $424 \mathrm{~m}^{3} / \mathrm{s}$. Korman and others (2004) did not incorporate temperature into these identified environments. Our study and Korman and others (2004) concluded that the variables of geomorphic features (for example, debris fans, talus slopes) and mainstem discharges most affect availability of low-velocity environments. At the confluence area, because the mainstem water temperature rarely exceeds LCR water temperatures in the months of June-August (Voichick and Wright, 2007), the discharge volume of the mainstem affects the direction around the confluence island that the warmer water from the LCR is routed, and it affects the availability of low-velocity, warmwater area. Under operations that increase mainstem temperatures (for example, reduced reservoir elevations, Voichick and Wright, 2007), and in association with discharges less than 400 $\mathrm{m}^{3} / \mathrm{s}$, warmer, low-velocity area at the confluence (fig. $6 \mathrm{~A}$, table 2 ) and at downstream sites that Korman and others (2004) identified would increase. Young fish may use these low-velocity areas even in the absence of warm water to reduce energetic demand associated with maintaining position, and may also use areas along boundary layers near the bottom of the measured channels or behind rocks that this study did not measure.

The daily effect of fluctuations of the Colorado River, which can include a $226-\mathrm{m}^{3} / \mathrm{s}$ change in discharge, can significantly decrease the area of available low-velocity, warm water at the confluence. For example, an initial discharge of $226 \mathrm{~m}^{3} / \mathrm{s}$ that is increased to $452 \mathrm{~m}^{3} / \mathrm{s}$ in a day will maximize available low-velocity, warmwater areas at the confluence to 1.2 ha when discharge reaches $368 \mathrm{~m}^{3} / \mathrm{s}$ (table 2), but an overall decrease in available area will eventually result as discharge volume exceeds $400 \mathrm{~m}^{3} / \mathrm{s}$ (table 2, fig. 7). Juvenile and YOY humpback chub occupying areas in the lower portion of the confluence would be subjected to thermal shock when the colder mainstem waters enter this area, reducing their ability to swim upstream through the high-velocity zones to the rearing and nursery environments of the LCR. These fish could be lost as drift and become easy prey for nonnative predators (Johnson and Carothers, 1987; Gorman and others, 2005; Gloss and Coggins, 2005). Daily repetition of flow variation, as described, sets the stage for a potential daily depredation of YOY and juveniles in the mainstem. In contrast, discharges that change in volume by half the daily maximum $\left(113 \mathrm{~m}^{3} / \mathrm{s}\right)$ with initial discharge of $226 \mathrm{~m}^{3} / \mathrm{s}$ would result in a net increase in suitable area over the course of the day from 0.2 ha to approaching 1.2 ha (table 2, fig. 6). Although this study has identified potential habitat, studies that assessed this operational affect on the movement of YOY fishes and density-dependent factors affecting growth 
and survival in these potential habitats would provide a more complete understanding of the mainstem and LCR dynamics and native fish recruitment.

At the time that these data were collected, the Secretary of the Interior had approved the implementation of two large-scale experimental resource management flows that mimicked, to some extent, predam hydrology and were designed to benefit targeted resources. The controlled flood in 1996 (Webb and others, 1999; Patten and Stevens, 2001) primarily focused on sediment dynamics, sediment conservation, and habitat restoration. The hydrograph in the spring and summer of 2000 was intended to benefit native fish, particularly humpback chub, by stabilizing habitat and consequently increase YOY survivorship (Gloss and Coggins, 2005; Melis and others, 2006). Both of these experiments were of short duration relative to the predam hydrograph and biological response time: 1 week in spring 1996, and several months in spring and summer 2000. The duration of ponding at $878 \mathrm{~m}^{3} / \mathrm{s}$ discharge lasted for 4 days in April 2000. Because spawning by native fish can take place over the course of 2 months (Gorman and Stone, 1999), it seems unlikely that a ponded area available for 4 days would result in increased spawning and spawning success.

In contrast, the sustained discharge of $226 \mathrm{~m}^{3} / \mathrm{s}$ that lasted for 3 months from June through August 2000 may have provided a stable habitat for YOY humpback chub emerging from the LCR that led to the increased recruitment modeled by Coggins and Walters (2009). Long-term mark recapture monitoring of humpback chub (1998-2007) indicate that the population is stabilizing from a decadal decline (Melis and others, 2006; Coggins and Walters, 2009). However, because of smearing among cohort years resulting from aging techniques that use fish length (Coggins and others, 2006b), it cannot be definitively said that survivorship increased as a result of the lower steady discharges. Subsequent mainstem warming associated with low reservoir elevations (Vernieu and others, 2005; Voichick and Wright, 2007) and predator removal initiated in 2003 (Gloss and Coggins, 2005) also contributed to survivorship and recruitment signal and preclude determining which variable had a greater effect on improving recruitment.

Furthermore, there is uncertainty about how changes in habitat availability, primarily depth and velocity variables, influences population dynamics. Although we identify low-velocity warm areas at low discharges, it may be the persistence of temperature or discharge variables that is important (Freeman and others, 2001; McKinney and others, 2001; Korman and Campana, 2009). Freeman and others (2001) compared regulated and unregulated portions of the Tallapoosa River that runs from Georgia and into Alabama. They determined that higher YOY abundance in the regulated portion was correlated with the presence of persistent habitat instead of with habitat availability or the amount of fluctuations in discharge. In the Lees Ferry reach of the Colorado River, Korman and Campana (2009) determined that extreme changes in discharge (for example, discharges that changed overnight from a June-August base flow of $339 \mathrm{~m}^{3} / \mathrm{s}$ to a September base flow of $226 \mathrm{~m}^{3} / \mathrm{s}$ ) negatively affected YOY rainbow trout survival because the stage of minimum daily discharge changed quickly. McKinney and others (2001) showed that the increased minimum flows from Glen Canyon Dam in Lees Ferry that started in 1996 (U.S Department of the Interior, 1996) provided persistent spawning grounds for rainbow trout, improved spawning success, and contributed to increased recruitment to the adult rainbow trout population. Although we determine that potential YOY humpback chub habitat increases and decreases at the confluence under variable mainstem discharges, uncertainty remains about factors that limit recruitment in native fish in the Colorado River with respect to habitat availability and persistent habitat, as well as other factors such as competition and predation. 
The spatial referencing of several environmental variables used in this investigation was critical to understanding the dynamic nature of the confluence area and the implications for potential YOY humpback chub habitat under different discharge volumes. Utilization of modern survey technology with adequate spatial control allowed the combination of physical data collected over several years (table 1) to be layered together to provide a reliable surface model of changes in the aquatic environment. Moreover, the results of these investigations are in a format conducive to GIS analysis with other information layers for multidisciplinary analysis, and they can be combined with radiotelemetry and substrate data for further habitat analysis. Spatial referencing that uses nationally accepted standards (for example, National Geodetic Survey and National Spatial Reference System) provides a locally and globally consistent framework for successful resource dataset integration and modeling.

\section{Management Implications}

Spatially referenced environmental datasets can be used to exclude experimental management scenarios that may provide little biological advantage to one resource and prove more costly to another resource. For restoration success, both the life history of the species that is the focus of restoration and the limitations of the potentially affected resource (for example, power generation) need to be considered. For example, during the summer, hydropower demands in the Southwestern United States conflict with fish-habitat restoration efforts below Glen Canyon Dam. Hydropower generation in summer (June-August) relies on fluctuating dam releases that result in release volumes that exceed the habitat preferences of YOY native fish along shorelines (Korman and others, 2004).Mortality rates for long-lived species, like humpback chub, are highest at emergence and taper off over the life of the organism (Douglas and Marsh, 1996). Mortality factors for fish include predation, disease, and other selection pressures. For the humpback chub in Grand Canyon, sustained high releases that target spawning cues and emergent life-history stages, such as those implemented in the spring 2000 (Valdez and others, 2000), may be less effective at increasing recruitment success than lower discharges that target YOYs and juveniles that emerge from the LCR in the later summer months. The results presented here and by Korman and others (2004) also indicate that under moderate daily fluctuations $\left(113 \mathrm{~m}^{3} / \mathrm{s}\right)$, low-velocity, warmwater areas increase with increasing discharges when mainstem discharge starts at $226 \mathrm{~m}^{3} / \mathrm{s}$. This information provides an additional variable to consider when developing plans around dam operations and resource tradeoffs.

Focusing on one or two variables, such as discharge magnitude and(or) duration, in attempts to mimic historical hydrology and meet the needs of species recovery or habitat restoration is problematic and potentially unrealistic. The magnitudes of discharges available under regulation are often less than 50 percent of the historical values, if not significantly less (Turner and Karpiscak, 1980; Topping and others, 2003), and the duration of a discharge has changed from months to days or hours. Adaptive management programs that embrace multiple management strategies may be more effective in eliciting positive responses by the target species or resource. Since the 2000 experiment, the Glen Canyon Dam Adaptive Management Program has incorporated predator control (Gloss and Coggins, 2005; Coggins, 2008), used short-duration, highmagnitude discharges to affect predator recruitment and improve shoreline habitat (Grams and others, 2010; Korman and others, 2010), and implemented two-month steady flow releases in the months of September and October since 2008 (U.S. Fish and Wildlife Service, 2008). Since 2000, one or more of these measures appear to have contributed to stabilizing recruitment in humpback chub (Coggins and Walters, 2009). The coincident regional drought and reduced reservoir 
elevations associated with increased mainstem discharge temperatures may have also contributed to a stabilized pattern of native fish recruitment.

\section{Acknowledgments}

This idea and approach for the work described in this report was developed by the late Frank Protiva of Shephard-Wesznitzer, Inc. Between the years 1990 and 2000, Frank was a major contributor to the development of the survey control network that exists along the Colorado River in Grand Canyon and made the results in this paper possible. Our work benefitted greatly from Frank's passion for using surveying and engineering approaches in environmental restoration. Funding for data collected in 2000 and for this report was provided by the Glen Canyon Dam Adaptive Management Program through the U.S. Geological Survey, Grand Canyon Monitoring and Research Center grant \#00PG400163.

\section{References Cited}

Anderson, C.R., and Wright S.A., 2007, Development and application of a water temperature model for the Colorado River ecosystem below Glen Canyon Dam, Arizona: Hydrological Science and Technology, v. 23, no. 1-4, Proceedings of the American Institute of Hydrology 2007 Annual Meeting and International Conference, p. 13-26.

Bulkley, R.V., Berry, C.R., Pimentel, R., and Black, T., 1981. Tolerance and preferences of Colorado River endangered fishes to selected habitat parameters: Utah Cooperative Fisheries Research Unit, Utah State University, Completion Report for the U.S. Fish and Wildlife Service, Contract 14-16-00018-1061 A-2, Logan.

Clarkson, R.W., and Childs, M.R., 2000, Temperature effects of hypolimnial-release dams on early life stages of Colorado River Basin big-river fishes: Copeia, v. 2, p. 402-412.

Coggins, L.G., Jr., 2008, Abundance trends and status of the Little Colorado River population of humpback chub — an update considering 1989-2006 data: U.S. Geological Survey Open-File Report 2007-1402, version 1.53 p.

Coggins, L.G., Jr., and Walters, C.J., 2009, Abundance trends and status of the Little Colorado River population of humpback chub — an update considering data from 1989-2008: U.S. Geological Survey Open-File Report 2009-1075, 18 p., accessed May 24, 2010, at http://pubs.usgs.gov/of/2009/1075/.

Coggins, L.G. Jr., Pine, W.E. III, Walters, C.J., Van Haverbeke, D.R., Ward, D. and Johnstone, H.C., 2006a, Abundance trends and status of the Little Colorado River population of humpback chub: North American Journal of Fisheries Management, v. 26, p. 233-245, DOI:10.1577/M05075.1 .

Coggins, L.G., Jr., Pine, W.E., III, Walters, C.J., and Martell, S.J.D., 2006b, Age-structured markrecapture analysis - a virtual population-analysis-based model for analyzing age-structured capture-recapture data: North American Journal of Fisheries Management, v. 26, p. 201-205.

Colton, H.S., 1937, Some notes on the original condition of the Little Colorado River - a side light on the problems of erosion: Museum Notes, Museum of Northern Arizona, v. 10, p. 17-20.

Converse, Y.K., Hawkins, C.P., and Valdez, R.A., 1998, Habitat relationships of subadult humpback chub in the Colorado River through Grand Canyon - spatial variability and implications for flow regulation: Regulated Rivers, Research \& Management, v. 14, p. 267-284. Cooley, M.E., 1976, Spring flow from pre-Pennsylvanian rocks in the southwestern part of the Navajo Indian Reservation, Arizona: U.S. Geological Survey Professional Paper 521-15 p. 
Douglas, M.E., and Marsh, P.C., 1996, Population estimates/population movements of Gila cypha, an endangered cyprinid fish in the Grand Canyon region of Arizona: Copeia, v. 1, p.15-28.

Freeman, M.C., Bowen, Z.H., Bovee, K.D., and Irwin, E.R., 2001, Flow and habitat effects on juvenile fish abundance in natural and altered flow regimes: Ecological Applications, v. 11, p. 179-190.

Gloss, S.P., and Coggins, L.G., Jr., 2005. Fishes of Grand Canyon, in Gloss, S.P., Lovich, J.E., and Melis, T.S., eds., The state of the Colorado River ecosystem in Grand Canyon: U.S. Geological Survey Circular 1282, p. 33-56.

Gorman, O.T., and Stone, D.M., 1999, Ecology of spawning humpback chub, Gila cypha, in the Little Colorado River near Grand Canyon, Arizona: Environmental Biology of Fishes, v. 55, p. $115-133$.

Gorman, O.T., Bramblett, R.G., Hervin, R.M., Van Haverbeke, D.R., and Stone, D.M., 2005, Distribution and abundance of native and non-native fishes of the Colorado River ecosystem in Grand Canyon, Arizona, in Brouder, M.J., Springer, C.L., and S. C. Leon, S.C., eds, The lower Colorado River - restoring natural function and native fish within a modified riverine environment: Albuquerque, New Mexico, U.S. Fish and Wildlife Service, Proceedings of July 89, 1998, and July 13-14, 1999, symposia in Las Vegas, p. 78-94.

Grams, P.E., Schmidt, J.C., and Andersen, M.E., 2010, 2008 high-flow experiment at Glen Canyon Dam-morphologic response of eddy-deposited sandbars and associated aquatic backwater habitats along the Colorado River in Grand Canyon National Park: U.S. Geological Survey Open-File Report 2010-1032, 73 p.

Hamman, R.L., 1982, Spawning and culture of humpback chub: Progressive Fish Culturalist, v. 44, no. 4, p. 213-216.

Hazel, J.E., Jr., Kaplinski, M., Parnell, R., Kohl, K., and Topping, D.J., 2006, Stage-discharge relations for the Colorado River in Glen, Marble, and Grand Canyons, Arizona: U.S. Geological Survey Open-File Report 2006-1243, 7 p.

Howard, A., and Dolan, R., 1981, Geomorphology of the Colorado River in the Grand Canyon: The Journal of Geology, v. 89, p. 269-298.

Johnson, P.W., and Sanderson, R.B., 1968, Spring flow into the Colorado River Lees Ferry to Lake Mead, Arizona: Arizona State Land Department, Water-Resources Report No. 34, 26 p.

Johnson, R.R., and Carothers, S.W., 1987, External threats - the dilemma of resource management on the Colorado River in Grand Canyon: Environmental Management, v. 11, p. 99-107.

Kaeding, L.R., and Zimmerman, M.A., 1983, Life history and ecology of the humpback chub in the Little Colorado and Colorado rivers of the Grand Canyon: Transactions of the American

Fisheries Society, v. 112, p. 577-594.

Kaplinski, M., Hazel, J.E., Jr., Parnell, R., Breedlove, M., Kohl, K., and Gonzales, M., 2009, Monitoring fine-sediment volume in the Colorado River ecosystem, Arizona-bathymetric survey techniques: U.S. Geological Survey Open-File Report 2009-1207, 33 p.

Korman, J., and Campana, S.E., 2009, Effects of hydropeaking on nearshore habitat use and growth of age-0 rainbow trout in a large regulated river: Transactions of the American Fisheries Society, v. 138, p. 76-87.

Korman, J., Wiele, S.M., and Torizzo, M., 2004, Modelling effects of discharge on habitat quality and dispersal of juvenile humpback chub (Gila cypha) in the Colorado River, Grand Canyon:

River Research and Applications, v. 20, p. 379-400. DOI:10.1002/rra.749

Korman, J., Kaplinski, M, and Melis, T.S., 2010, Effects of high-flow experiments from Glen Canyon Dam on abundance, growth, and survival rates of early life stages of rainbow trout in the 
Lees Ferry reach of the Colorado River: U.S. Geological Survey Open-File Report 2010-1034, $31 \mathrm{p}$.

Marsh, P.C., 1985, Effect of incubation temperature on survival of embryos of native Colorado River fishes: Southwestern Naturalist, v. 30, no. 1, p. 129-140.

McKinney, T., Speas, D.W., Rogers, R.S., and Persons, W.R., 2001, Rainbow trout in a regulated river below Glen Canyon Dam, AZ, following increased minimum flows and reduced discharge variability: North American Journal of Fisheries Management, v. 21, p. 216-222.

Melis, T.S., Martell, S.J.D., Coggins, L.G., Pine, W.E., III, and Andersen, M.E., 2006, Adaptive management of the Colorado River ecosystem below Glen Canyon Dam, Arizona - using science and modeling to resolve uncertainty in river management: Proceedings of Adaptive Management of Water Resources AWRA Summer Specialty Conference, Missoula, Montana, June 26-28, 2006, 6 p.

Miller, R.R., 1946, Gila cypha, a remarkable new species of cyprinid fish from the Colorado River in Grand Canyon, Arizona: Journal of the Washington Academy of Science, v. 36, p. 409-415.

Minckley, W.L., 1991, Native fishes of the Grand Canyon region - an obituary?, in Colorado River Ecology and Dam Management: Washington, D.C., National Research Council, National Academy Press, p. 124-177.

Oberlin, G.E., Shannon, J.P., and Blinn, D.W., 1999, Watershed influence on the macroinvertebrate fauna of ten major tributaries of the Colorado River through Grand Canyon, Arizona:

Southwestern Naturalist, v. 44, p. 17-30.

Patten, D.T., and Stevens, L.E., 2001, Restoration of the Colorado River ecosystem using planned flooding: Ecological Applications, v. 11, no. 3, p. 633-710.

Poff, N.L., Allan, J.D., Bain, M.B., Karr, J.R., Prestegaard, K.L., Richter, B.D., Sparks, R.E. and Stromberg, J.C., 1997, The natural flow regime- a paradigm for river conservation and restoration: BioScience, v. 47, p. 769-784.

Poff, N.L., Richter, B.D., Arthington, A.H., Bunn, S.E., Naiman, R.J., Kendy, E., Acremen, M., Apse, C., Bledsoe, B.P., Freeman, M.C., Henricksen, J., Jacobson, R.B., Kennen, J.G., Merritt, D.M., O'Keeffe, J.H., Olden, J.D., Rogers, K., Tharme, R.E., and Warner, A., 2010, The ecological limits of hydrologic alteration (ELOHA) - a new framework for developing regional environmental flow standards: Freshwater Biology, v. 55, p. 147-170.

Robinson, A.T., and Childs, M.R., 2001, Juvenile growth of native fishes in the Little Colorado River and in a thermally modified portion of the Colorado River: North American Journal of Fisheries Management, v. 21, p. 809-815.

Robinson, A.T., Clarkson, R.W., and Forrest, R.E., 1998, Dispersal of larval fishes in a regulated river tributary: Transactions of the American Fisheries Society, v. 127, p. 772-786.

Schmidt, J.C., and Graf, J.B., 1990, Aggradation and degradation of alluvial-sand deposits, 1965 to 1986, Colorado River, Grand Canyon National Park, Arizona: U.S. Geological Survey Professional Paper 1493, 74 p. Schmidt and Graf, 1990

Stanford, J.A., and Ward, J.V., 1991, Limnology of Lake Powell and the chemistry of the Colorado River, in Colorado River Ecology and Dam Management: Washington, D.C., National Research Council, National Academy Press, p. 75-101.

Stone, D.M., and Gorman, O.T., 2006, Ontogenesis of endangered humpback chub (Gila cypha) in the Little Colorado River, Arizona: American Midland Naturalist, v. 155, p.123-135.

Stone, D.M., Van Haverbeke, D.R., Ward, D.L., and Hunt, T.A., 2007, Dispersal of nonnative fishes and parasites in the intermittent Little Colorado River, Arizona: The Southwestern Naturalist, v. 52, p. 130-137. 
Topping, D.J., Schmidt, J.C., and Vierra, L.E., Jr., 2003, Computation and analysis of the instantaneous-discharge for the Colorado River at Lees Ferry, Arizona-May 8, 1921, through September 30, 2000: U.S. Geological Survey Professional Paper 1677, 118 p.

Turner, R.M., and Karpiscak, M.M., 1980, Recent vegetation changes along the Colorado River between Glen Canyon Dam and Lake Mead, Arizona: U.S. Geological Survey Professional Paper 1132. $125 p$.

U.S. Department of the Interior, 1996, Record of decision, operation of Glen Canyon Dam final environmental impact statement: Washington, D.C., Office of the Secretary of Interior, $15 \mathrm{p}$.

U. S. Fish and Wildlife Service, 1990, Humpback chub recovery plan: U. S. Fish and Wildlife Service, Region 6, Denver, Colorado, 49 p.

U.S. Fish and Wildlife Service, 1995, Final biological opinion on the operation of Glen Canyon Dam: Albuquerque, N. Mex., consultation no. 2-21-93-F-167, p. 56.

U.S. Fish and Wildlife Service, 2008, Final biological opinion for the operation of Glen Canyon Dam: Phoenix, AZ, February 27, 2008, 88 p.

U.S. Geological Survey, 2010, National Water Information System (NWISWeb): U.S. Geological Survey database, accessed March 20, 2010, at http://waterdata.usgs.gov/nwis.

U.S. Geological Survey, 2007, Science plan for potential 2008 experimental high flow at Glen Canyon Dam: Flagstaff, Ariz., Southwest Biological Science Center, Grand Canyon Monitoring and Research Center, $104 \mathrm{p}$.

Valdez, R.A., and Hoffnagle, T.L., 1999. Movement, habitat use and diet of adult humpback chub, in Webb, R.H., Schmidt, J.C., Marzolf, G.R., and Valdez, R.A. eds., The controlled flood in Grand Canyon: Washington, D.C., American Geophysical Union, Geophysical Monograph 110, p. 297-307.

Valdez, R.A., and Ryel, R.J., 1995, Life history and ecology of the humpback chub (Gila cypha) in the Colorado River, Grand Canyon, Arizona: Logan, Utah, BIO/WEST, Inc., Final report to the Bureau of Reclamation, Salt Lake City, Utah, contract no. 0-CS-40-09110.

Valdez, R.A., Carothers, S.W., House, D.A., Douglas, M.E., Douglas, M., Ryel, R.J., Bestgen, K.R., and Wegner, D.L., 2000, A program of experimental flows for endangered and native fishes of the Colorado River in Grand Canyon: Final report to U.S. Department of Interior, Grand Canyon Monitoring and Research Center, Flagstaff, Arizona, SWCA, Inc. Environmental Consultants, $68 \mathrm{p}$.

Vernieu, W.S., Hueftle, S.J., and Gloss, S.P., 2005, Water quality in Lake Powell and the Colorado River, in Gloss, S.P., Lovich, J.E., and Melis, T.S., eds., The state of the Colorado River ecosystem in Grand Canyon: U.S. Geological Survey Circular 1282, p. 69-85.

Voichick, N., and Wright, S.A., 2007, Water-temperature data for the Colorado River and tributaries between Glen Canyon Dam and Spencer Canyon, Northern Arizona, 1988-2005: U.S. Geological Survey Data Series 251, 24 p., accessed February 1, 2010, at http://pubs.usgs.gov/ds/2007/251/.

Webb, R.H., Schmidt, J.C., Marzolf, G.R., and Valdez, R.A. eds., 1999, The controlled flood in Grand Canyon: Washington, D.C., American Geophysical Union, Geophysical Monograph Series, v. 110, 367 p.

Wright, S.A., Anderson, C.R., and Voichick, N., 2008, A simplified water temperature model for the Colorado River below Glen Canyon Dam: River Research and Applications, v. 25, p. 675686. 
This page was intentionally left blank. 


\section{$\frac{\mathbb{3}}{\mathbb{3}}$}

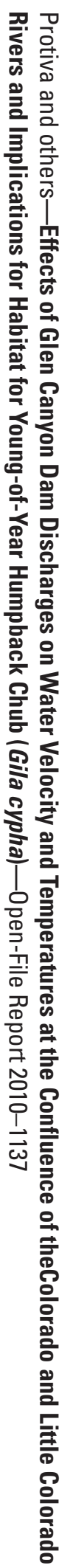

